\title{
Intraspecific Carbon and Nitrogen Isotopic Variability in Foxtail Millet (Setaria italica)
}

\author{
Emma Lightfoot ${ }^{1}$, Natalia Przelomska ${ }^{2}$, Martha Craven ${ }^{2}$, Tamsin C. O'Connell ${ }^{2}$, \\ $\mathrm{Lu} \mathrm{He}^{3}$, Harriet V. Hunt ${ }^{1}$ and Martin K. Jones ${ }^{2}$ \\ ${ }^{1}$ McDonald Institute for Archaeological Research, University of Cambridge, \\ Downing Street, Cambridge, CB2 3ER, UK \\ ${ }^{2}$ Department of Archaeology and Anthropology, University of Cambridge, Downing \\ Street, Cambridge, CB2 3DZ, UK \\ ${ }^{3}$ College of Agriculture, Shanxi Agricultural University, Taigu, 030801, China
}

Corresponding Author: Emma Lightfoot, McDonald Institute for Archaeological Research, University of Cambridge, Downing Street, Cambridge, CB2 3ER, UK, elf12@cam.ac.uk,+44 (0)1223339326

Short title: Carbon and Nitrogen Isotopic Variability in Foxtail Millet

Key words: $\mathrm{C}_{4}$, grains, leaves, cereals, palaeodiet.

Grant sponsor: European Research Council (GA249642)

\begin{abstract}
RATIONALE: Isotopic palaeodietary studies generally focus on bone collagen from human and/or animal remains. While plant remains are rarely analysed, it is well known that plant isotope values can vary as a result of numerous factors, including soil conditions, the environment and type of plant. The millets were important food crops in prehistoric Eurasia, yet little is known about the isotopic differences within millet species.
\end{abstract}

METHODS: Here we compare the stable isotope ratios within and between Setaria italica plants grown in a controlled environment chamber. Using homogenized samples, we compare carbon isotope ratios of leaves and grains, and nitrogen isotope ratios of grains from 29 accessions of Setaria italica.

RESULTS: We find significant isotopic variability within single leaves and panicles, and between leaves and panicles within the same plant, which must be considered when undertaking plant isotope studies. We find that the leaves and grains from the different accessions have a c. $2 \%$ range in $\delta^{13} \mathrm{C}$ values, while the nitrogen isotope values in the grains have a $c$. $6 \%$ range. We also find an average offset of $0.9 \%$ between leaves and grains in $\delta^{13} \mathrm{C}$ value.

CONCLUSIONS: The variation found is large enough to have archaeological implications, and within- and between-plant isotope variability should be considered in isotope studies. The range in $\delta^{15} \mathrm{~N}$ values is particularly significant as it is larger than the typical values quoted for a trophic level enrichment, and as such may lead to erroneous interpretations of the amount of animal protein in human or animal diets. It is therefore necessary to account for the variability in plant stable isotope values during palaeodietary reconstructions.

\section{INTRODUCTION}

Stable isotope studies rely on the premise that "you are what your eat", but in order to fully understand human and animal diets it is necessary to isotopically characterize 
both the plant and animal components of the diet itself. Until recently plant foods were rarely analysed as part of palaeodietary studies and even now charred plant remains are more often studied in their own right rather than as part of an integrated palaeodietary study. ${ }^{[1-4]}$ Nevertheless, variation in plant isotopes is a significant factor in need of consideration in palaeodietary studies. Plant isotope values vary between different tissues of the same plant, as well as between different plants of the same species, based on genetic and environmental factors. ${ }^{[5,6]}$ Where people and/or animals are eating different parts of a plant or different varieties of a species, the differences in plant isotope values can influence the human and animal data, and thus our understanding of the past. ${ }^{[7]}$ In order to fully interpret human or animal isotope data, therefore, it is necessary to have a good understanding of the isotopic variability in plants.

Two millet species (Setaria italica and Panicum miliaceum) were important food crops in prehistoric Eurasia, from China to Eastern Europe. They have various advantages over other major food crops, including: a relatively short growing season which can be three months or less; a relatively high nutritional value in terms of protein, vitamins and minerals compared to wheat, rice and maize; high water use efficiency; and the ability to grow on poor soils. ${ }^{[8-10]}$ As the millets were the only $\mathrm{C}_{4}$ plants likely to have been consumed on a significant scale in prehistoric Eurasia, they are particularly suited as a topic for stable isotope research due to the isotopic differences between $\mathrm{C}_{3}$ and $\mathrm{C}_{4}$ plants. With the growth of archaeological research in China, Central Asia and Eastern Europe, there is increasing interest in the role of millet in prehistoric societies. Millet consumption has been shown both isotopically ${ }^{[11]}$ and archaeobotanically ${ }^{[12]}$ across prehistoric Eurasia. It is likely that humans utilized both the grains and leaves; on some farms today, millet grains are consumed by humans or used as feed while the leaves are used as fodder. ${ }^{[13]}$ It is now timely to consider further the variation in isotopic values of millet and the implications this has on our interpretation of human and animal isotopic data.

This paper describes the results of analyses of foxtail millet (Setaria italica) samples grown in a controlled environment chamber. Foxtail millet was chosen for this study for several reasons: it is of considerable archaeological interest, being the dominant crop in northern China from the Middle Neolithic. ${ }^{[14]}$ It is known to show high levels of intraspecific genetic variability, ${ }^{[15]}$ and the recent sequencing of the complete genome of foxtail millet ${ }^{[16,17]}$ paves the way for analysis of the functional genetic variation underlying phenotypic variability. Foxtail millet also has a relatively short life cycle, which can be three months or less, ${ }^{[10,18]}$ facilitating experimental work. We characterize the carbon and nitrogen isotope variation between millet accessions (a plant or grain sample, variety or population, collected from a particular area and kept in a gene bank for conservation, cultivation and research), to consider the effect that genetic variation has upon isotope values. Furthermore, we compare the carbon isotope values of the two major edible tissues, grains and leaves, to consider the effect that eating different plant parts would have on consumer isotopic values. In order to achieve these aims, we first characterize the variation within a leaf and panicle, between leaves and panicles from the same plant, and between plants derived from a single grain of the same accession (S1 selfed progeny, i.e. the progeny of a plant where the only pollen that could reach the stigma of the flowers was the pollen from the anthers of that same plant) grown in different areas of the controlled environment chamber. 


\section{SCIENTIFIC BACKGROUND}

\section{$\mathrm{C}_{4}$ Photosynthesis and Isotope Discrimination}

One of the major uses of stable carbon isotope analysis is to distinguish between the consumption of two types of plants with different photosynthetic pathways, $\mathrm{C}_{3}$ and $\mathrm{C}_{4}$. As the stable isotope technique is relatively insensitive to minor dietary components, only staple plant foods are likely to influence human and animal isotope values. ${ }^{[18]}$ Most plants use the $\mathrm{C}_{3}$ photosynthetic pathway, including wheat, barley, potatoes and rice, while staple $\mathrm{C}_{4}$ plants include maize, sugar cane, sorghum and the millets. It is well-established that $C_{3}$ plant $\delta^{13} \mathrm{C}$ values are affected by multiple environmental and genetic factors. ${ }^{[19,20]}$ The latter cause slight differences in the way that plants control intercellular $\mathrm{CO}_{2}$ in response to the environment. ${ }^{[19,20]} \mathrm{C}_{4}$ plants, on the other hand, are thought to show little isotopic variability as they are relatively insensitive to environmental conditions. ${ }^{[21]}$

Both the $\mathrm{C}_{3}$ and $\mathrm{C}_{4}$ photosynthetic pathways discriminate against ${ }^{13} \mathrm{C}$ during uptake of $\mathrm{CO}_{2} . \mathrm{C}_{3}$ plants discriminate against ${ }^{13} \mathrm{C}$ more than $\mathrm{C}_{4}$ plants, leading to a bimodal distribution of plant carbon isotope values, ${ }^{[22]}$ which is then passed up the foodchain to animals and humans. The theoretical basis for isotope discrimination in $\mathrm{C}_{3}$ plants is well understoodand is largely controlled by the diffusion of $\mathrm{CO}_{2}$ through the stomata and the action of enzymes. ${ }^{[19]}$ The variation in discrimination against ${ }^{13} \mathrm{C}$ is related to water use efficiency and plant yield.

While isotopic discrimination in $\mathrm{C}_{4}$ plants is less well-understood, a theoretical basis has been proposed. ${ }^{[23]}$ As well as the stomatal and enzymatic components, the dissolution and hydration of $\mathrm{CO}_{2}$ and $\mathrm{CO}_{2}$ leakage from bundle sheath cells are important. Essentially, $\mathrm{C}_{4}$ plants are less sensitive to the partial pressure of $\mathrm{CO}_{2}$ inside the leaf mesophyll and in the atmosphere (because primary fixation of $\mathrm{CO}_{2}$ occurs efficiently at lower concentrations), and discrimination should increase as the concentration of the enzyme phosphoenolpyruvate (PEP) carboxylase increases or as the amount of $\mathrm{CO}_{2}$ that leaks out of the bundle sheath cells increases. ${ }^{[24]}$ Three different biochemical $\mathrm{C}_{4}$ subtypes exist, which use different enzymes to release $\mathrm{CO}_{2}$ in the bundle sheath cells. These subtypes show small but significant differences in $\delta^{13} \mathrm{C}$ values when grown under controlled conditions, although the reasons for this are not fully understood. ${ }^{[5,25,26]}$ Setaria italica uses the NADP-ME (NADP-malic enzyme) pathway, the pathway that generally has the highest $\delta^{13} \mathrm{C}$ values when plants of different subtypes are grown under controlled conditions. ${ }^{[25,26]} \mathrm{C}_{4}$ plants are more efficient in terms of water- and nitrogen-use than $\mathrm{C}_{3}$ plants, plus have higher light-use efficiencies at temperatures over $25-30^{\circ} \mathrm{C} .^{[27,28]}$

Studies of plant isotope values indicate that $\mathrm{C}_{4}$ plant material has a smaller range of $\delta^{13} \mathrm{C}$ values than $\mathrm{C}_{3}$ plant material. ${ }^{[22]}$ Nevertheless, average isotope values vary between $\mathrm{C}_{4}$ species related to differences in bundle sheath anatomy among biochemical $\mathrm{C}_{4}$ subtypes. ${ }^{[26,29]}$ Differences have also been shown within different varieties of the same species, with ranges of up to $2.2 \%$ reported in maize, ${ }^{[30]}$ small but significant differences found between 12 diverse genotypes of sorghum (up to $0.6 \%$ in mean discrimination values) ${ }^{[31]}$ and a small difference found between two genotypes of Panicum coloratum (0.8\%o). ${ }^{[32]}$ In field trials of 13 varieties of foxtail 
millet, $\delta^{13} \mathrm{C}$ values of both grains and leaves were found to vary by $c .1 \%$ o between varieties. ${ }^{[33]}$

In terms of environmental differences, $\mathrm{C}_{4}$ plant $\delta^{13} \mathrm{C}$ values have been found to vary with light intensity (18 species of $\mathrm{C}_{4}$ grasses, ${ }^{[34]}$ Miscanthus giganteus, ${ }^{[35]}$ Zea mays, Miscanthus $x$ giganteus and Flaveria bidentis $\left.{ }^{[36]}\right)$, water availability (18 species of $\mathrm{C}_{4}$ grasses, ${ }^{[34]}$ Bothriochloa ischaemum ${ }^{[37]} 18$ species of $\mathrm{C}_{4}$ grasses ${ }^{[38]}$ ), salinity (Zea mays and Andropogon glomeratus, ${ }^{[39]}$ Saccharum spp. hybrid ${ }^{[40]}$ ), latitude (Setaria italica) ${ }^{[33]}$ and altitude (Setaria viridis). ${ }^{[41]}$ It should be noted, however, that not all studies observe these relationships, for example no relationship was found between the $\delta^{13} \mathrm{C}$ values of $\mathrm{C}_{4}$ plants and mean annual rainfall in southern Africa. ${ }^{[42]}$

$\mathrm{C}_{4}$ plant carbon isotope values vary between plant part and biochemical fractions. Studies suggest that maize grains have $\delta^{13} \mathrm{C}$ values that are c. $1.5 \%$ higher than leaves, ${ }^{[43,44]}$ whereas roots of $\mathrm{C}_{4}$ plants tend to have similar or slightly lower $\delta^{13} \mathrm{C}$ values than leaves (as shown in studies of Pennisetum purpureum, ${ }^{[45]}$ Andropogon brazzae, Ctenium newtonii, Loudetia spp and Cyperus spp,${ }^{[46]}$ Brachiaria humidicola ${ }^{[47]}$ and Saccharum officinarum ${ }^{[48]}$ ). Alkanes and lipids have been shown to have $\delta^{13} \mathrm{C}$ values that are $8-10 \%$ lower than those of bulk leaf matter (as shown in studies of: Saccharum officinarum, Miscanthuys sacchariflorum and Zea mays, ${ }^{[49]}$ and Zea mays, Zoysia japonica, Saccharum officinarum and Sorghum bicolor ${ }^{[50]}$ ). Plant cellulose $\delta^{13} \mathrm{C}$ values tend to be higher than lignin (Spartina alterniflora and Cyndon dactylon, ${ }^{[51]}$ Brachiaria humidicola ${ }^{[47]}$ ). A previous study of Setaria italica grown in field trials suggests that the grains have $\delta^{13} \mathrm{C}$ values on average $0.8 \%$ higher than leaves. ${ }^{[33]}$

The variation in carbon isotope values within and between $\mathrm{C}_{4}$ plants is therefore large enough to be of interest to archaeologists, but few studies have yet been carried out on millet species.

\section{Nitrogen Uptake and Isotope Discrimination}

Nitrogen isotope values are used in palaeodietary studies to consider the proportion of animal (terrestrial or aquatic) protein in the diet of an individual. This is possible because nitrogen isotope values increase by $3-5 \%$ per trophic level, although the mechanism for this is not fully understood. ${ }^{[52-54]}$

The nitrogen isotopic values of plants reflect that of their source nitrogen, modified by fractionation during nitrogen uptake, metabolism and distribution. The source nitrogen-containing compounds, atmospheric nitrogen (for nitrogen-fixing plants), and nitrogenous compounds $\left(\mathrm{NH}^{4+}\right.$ and $\mathrm{NO}_{3}{ }^{-}$), have different nitrogen isotope ratios and therefore the plant $\delta^{15} \mathrm{~N}$ value reflects the proportion of each of these compounds utilized, as well as the different discrimination factors that occur for each. ${ }^{[55,56]}$ The factors that control total soil $\delta^{15} \mathrm{~N}$ values are complex but include: the composition of the soil $;{ }^{[55,56]}$ whether the soil is part of an open or closed system; ${ }^{[57,58]}$ the age, and therefore often depth, of the soil; ${ }^{[59,60]}$ climate, particularly rainfall:; ${ }^{[61]}$ salinity; ${ }^{[62]}$ the amount of animal matter; ${ }^{[63]}$ and altitude. ${ }^{[64]}$ In general, the soil $\delta^{15} \mathrm{~N}$ value increases as depleted mineral nitrogen compounds are lost due to nitrification, ammonia volatilization and leaching. ${ }^{[65]}$ The soil has reduced $\delta^{15} \mathrm{~N}$ values when the input of 
depleted nitrogen exceeds its loss.

Uptake and fixation of nitrogen from the soil involves various fractionations, and cooccurring plant species can have large variability in $\delta^{15} \mathrm{~N}$ values, with a range of $10 \%$ reported. ${ }^{[6]}$ The fractionation during nitrogen fixation in legumes is not well understood, with studies reporting both discrimination for and against ${ }^{15} \mathrm{~N} .{ }^{[67]}$ In nonleguminous plants, fractionation during nitrogen fixation is influenced by various factors, for example the type of mycorrhiza: plants with ectomycorrhiza and ericoid mycorrhiza usually have lower $\delta^{15} \mathrm{~N}$ values than plants with arbuscular mycorrhiza or no mycorrhiza. ${ }^{[6,68]}$ The plant morphology and tissue type affect the $\delta^{15} \mathrm{~N}$ value, with $\delta^{15} \mathrm{~N}$ value declining with longevity and woodiness, such that herbaceous annuals have the highest $\delta^{15} \mathrm{~N}$ values followed by perennial herbs, shrubs and trees. ${ }^{[69]}$ The penetration depth of the roots could also be a factor in $\delta^{15} \mathrm{~N}$ variation, due to the variations in soil $\delta^{15} \mathrm{~N}$ value with depth. ${ }^{[66]}$ Isotopic differences also exist within plants of the same species when different genotypes are grown under the same conditions, with whole plant Hordeum spontaneum $\delta^{15} \mathrm{~N}$ values varying by $1.3 \%$ among genotypes, ${ }^{[70]}$ while another experiment on the same species found $2.2 \%$ differences between shoots. ${ }^{[71]}$

Finally, different plant parts have been shown to have different $\delta^{15} \mathrm{~N}$ values, determined by the $\delta^{15} \mathrm{~N}$ values of influx and efflux nitrogen after metabolism in the organ. Growing parts (such as expanding leaves and filling grains), for example, are supplied with nitrogen by two sources, currently-absorbed nitrogen and re-allocated nitrogen. Studies have shown that grains have higher $\delta^{15} \mathrm{~N}$ values than rachises in wheat (Triticum aestivum) ${ }^{[72]}$ and that leaves have higher $\delta^{15} \mathrm{~N}$ values than roots in tomato plants (Lycopersicon esculentum) ${ }^{[73]}$ and komatsuna (Japanese spinach leaf, Brassica campestris). ${ }^{[7]}$

The increase in plant $\delta^{15} \mathrm{~N}$ values with aridity is of particular importance to archaeology, as in arid climates it can be difficult to distinguish between individuals consuming marine and $\left(\mathrm{C}_{4}\right)$ terrestrial diets. ${ }^{[75,76]} \mathrm{As} \mathrm{C}_{4}$ plants are adapted to arid conditions, this may cause difficulties in determining the amount of animal protein consumed by an individual or animal that eats a lot of millet. Indeed, several studies have suggested that an aridity effect accounts for high bone collagen $\delta^{15} \mathrm{~N}$ values of inland human populations consuming millet. ${ }^{[77,78]}$ It is worth noting, however, that several studies on agricultural $\left(\mathrm{C}_{3}\right)$ species have not shown an aridity effect, which may suggest that in agricultural settings other factors over-ride or mitigate any aridity effect or that such effects can only be seen on a community, rather than individual species, level. ${ }^{[79,80]}$

The variations in $\delta^{15} \mathrm{~N}$ values of plants are therefore of interest to archaeologists but are rarely analysed to provide baseline data for human or animal diets. Furthermore most studies do not consider the effect of humans and animals eating different plant parts with different $\delta^{15} \mathrm{~N}$ values.

\section{MATERIALS AND METHODS}

A total of 40 accessions of Setaria italica were analysed isotopically in this study. These were selected from a larger set of 360 accessions, for which grain was obtained 
from five germplasm banks: the National Institute of Agrobiological Sciences, Japan (NIAS); Leibniz-Institut für Pflanzengenetik und Kulturpflanzenforschung, Gatersleben, Germany (IPK Gatersleben); the N.I. Vavilov Institute of Plant Genetic Resources, Russia (VIR); The International Crops Research Institute for the SemiArid Tropics, India (ICRISAT); and the United States Department of Agriculture Agricultural Research Centre (USDA-ARS), for a wider project on foxtail millet genetic diversity. Accessions are defined as such by the curating germplasm bank and sent as samples of typically several hundred grains. They are derived from samples of local varieties, originally collected from across Eurasia and parts of Africa and presumed to be adapted to the climatic conditions in their regions of origin (full details of the samples used in this study are given in Table S1). What constitutes a distinct sample or accession will depend on the opinions of the original collector, and the genetic diversity within accessions will further by shaped by the regeneration programme of the germplasm bank in which they are maintained, and thus will be variable between accessions. In previous years' experimental work on our collection, randomly chosen grains from each accession were sown and plants grown to maturity, with panicles bagged to prevent cross-pollination. The resulting S1 selfed grain was harvested, and this grain was used in the current experiment. Therefore, in the following, each accession was represented by grain derived from a single plant grown from the original germplasm, hereafter designated 'lines'. Because $S$. italica is largely self-pollinating, within-plant heterozygosity is expected to be very low, and therefore the grain within a single line should be highly genetically similar.

The accessions were sown in a Conviron controlled environment chamber (hereafter growth chamber) at the Sainsbury Laboratory, University of Cambridge, Bateman Street, Cambridge, CB2 1LR (12 hours of daylight, $350 \mu$ moles light level, $28^{\circ} \mathrm{C}$ day time temperature, $22{ }^{\circ} \mathrm{C}$ night time temperature and $65 \%$ humidity). All plants were grown in the same type of compost (John Innes no. 2: 40\% peat, 40\% soil, 20\% grit with fertilizer, $6 \% \mathrm{~N}, 8 \% \mathrm{P}$ and $11 \% \mathrm{~K}$, supplied by the Sainsbury Laboratory) and were watered with tap water every day in the initial fortnight and thereafter approximately every second day (i.e. when the soil was getting dry). The plants were grown in ten blocks in the growth chamber. For most lines, one plant was grown in a randomly allocated location. For eleven lines, one plant was grown in a randomly allocated place in each of the ten blocks (ten plants in total per line). Plants from these replicated lines were chosen for the intra-plant and growth chamber variation studies.

For each day of the growth trial, plants were checked for heading (when the panicle first becomes visible upon inspection of the flag leaf sheath). This was recorded as the date of flowering and days to flowering were calculated from the sowing date. The following characteristics were measured on the day of flowering: intensity of green of the whole plant - on a relative scale of 1 to 3 , where 1 was pale and 3 was dark green; height of plant - from the soil to the base of the flag leaf; number of tillers (secondary stems); habit of the plant (how much the tillers spread out) where 0 denotes horizontal or nearly so, 1 denotes spreading tillers, but at an angle of less than 30 degrees and 2 denotes highly spread out tillers at an angle of 30 degrees or more; and number of leaves, where leaves on tillers were counted as well. The number of panicles was counted once the plant had matured and dried out. Geographic information (coordinates) were provided with the germplasm or estimated based on the information provided with the grain (for example, if a province of a country was provided, coordinates were found for the central point of that province). Photoperiod 
sensitivity was measured by subtracting the number of days to flowering in the growth chamber (with its short photoperiod) from the number of days to flowering under a long day photoperiod (from a prior experiment in a greenhouse over the summer, at $52^{\circ} \mathrm{N}$ ). The greater this difference, the greater the photoperiod sensitivity, with the premise that photoperiod-sensitive plants delay flowering under long days, in anticipation of a favourable short photoperiod. This is an approximate measure that has been used for example in rice and maize, other plants responsive to a short critical photoperiod. ${ }^{[81,82]}$

The plants were harvested when the grains were mature, or after 4 months, whichever was earlier. If the grains were mature, the whole plant was placed into one or more $50 \mathrm{ml}$ transport tubes. For the plants that were not mature at harvest, samples of leaves and grains were taken into smaller tubes. All samples were frozen and then freezedried. When samples were selected for analysis, priority was given to plants for which the whole plant was available. A series of experiments were conducted on these plants which are described below and summarized in Table 1. Sample sizes were chosen for a variety of reasons: to provide enough data for statistically reliable results; availability of samples; and to provide a representative variety of source locations and plant characteristics.

One plant was chosen at random from each of six of the replicated lines for intra-leaf and intra-panicle analysis (Table 2). Samples were taken for carbon isotope analysis from approximately equally spaced points along a leaf from six plants of each line. Single grains were taken from points spread along a single panicle from the same six plants for carbon and nitrogen isotope analysis. For nitrogen, whole grains were analysed, while for carbon the grains were crushed and an appropriate amount taken for analysis.

In order to characterize isotopic differences between leaves from one plant, a further plant was sampled from the same six lines (in one case the same individual plant was used as for the intra-leaf and intra-panicle study: Table 3). As far as possible, all leaves were sampled from each of these plants, a total of 74 leaves, ranging from 8 to 23 leaves per plant. Each of these 74 leaves was prepared and analysed for carbon isotope values (see below). It was not possible to use the same six plants to quantify the isotopic differences between panicles, as not all accessions have multiple panicles - some accessions typically have a less branching habit and tend to have a single stem, with one large panicle, while others are more highly branched and have multiple stems with multiple, smaller panicles. Instead, 11 plants were chosen from four of the replicated lines (including four of the plants analysed for intra-plant leaf differences; Table 4). All panicles were sampled from these 11 plants, a total of 36 panicles, ranging from two to six panicles per plant. Each panicle was prepared and analysed for carbon and nitrogen isotope values (see below).

Replicated line SIT0034 was chosen to assess intra-line isotopic variation, where ten of the same line were grown in different locations within the growth chamber. Intraline isotopic variation might be due to environmental variation across the growth chamber in the soil or air (e.g. due to edge effects) or residual genetic variation among the S1 selfed grain. All of the leaves from each of the ten plants were prepared and analysed together for their carbon isotope ratio (see below). Each plant had only one panicle which was analysed for carbon and nitrogen isotope values. 
Finally, 29 further accessions were chosen as a representative subset of the 360 accessions to analyse inter-accession variability within Setaria italica (Table 5). The samples were chosen to give a wide range of geographic locations of origin (see Table $\mathrm{S} 1$ for full sample information). Data on genetic variation in these accessions is not yet available, but high intraspecific genetic diversity in $S$. italica has been found in other studies. ${ }^{[83]}$ We therefore assumed that the among-accession genetic variability in our sample set will be reasonably high, considering the range of locations and climates of origin. All of the leaves from each of the 29 plants were prepared and analysed together for carbon isotope values (see below). All of the panicles from each plant were prepared and analysed together for carbon and nitrogen isotope values (see below).

With the exception of the samples taken for intra-leaf analysis, leaves were chopped by hand and ground in a Qiagen Retsch TissueLyser (Skelton House, Lloyd Street North, Manchester, M15 6SH). For grains, with the exception of the intra-panicle analysis, $c$. 20-30 grains were taken from one or more panicles, as appropriate, and ground together by hand for analysis. For carbon isotope analysis the sample size analysed for leaf and grain was $0.8-1.0 \mathrm{mg}$. For nitrogen isotope analysis of grains, the sample size was calculated for each plant based in the percentage nitrogen values obtained in the carbon isotope analysis of the grain, typically $2-4 \mathrm{mg}$.

Samples were analyzed using a Costech elemental analyzer coupled in continuousflow mode to a Thermo Finnigan MAT253 mass spectrometer at the Godwin Laboratory, University of Cambridge. Carbon and nitrogen stable isotope values are expressed as delta values (e.g. $\delta^{13} \mathrm{C}$ ) relative to international standards (VPDB and AIR, respectively) ${ }^{[84,85]}$ in units of permil (parts per thousand, \%o). ${ }^{[86]}$ Repeated measurements on international and in-house standards (alanine, BLS, caffeine, EMC, nylon and protein 2) showed that the analytical error was less than $<0.2 \%$ for both carbon and nitrogen. Where possible, that is where the grains or leaves were homogenized, samples were run in triplicate. The reproducibility across the triplicate analyses (generally $<0.2 \%$ ) indicates that the samples were homogenized well. For the analysis of variation within a single leaf or panicle the data represent a single analysis. For leaf nitrogen, large sample sizes (up to $10 \mathrm{mg}$ ) were needed in order to obtain sufficient nitrogen for analyses. Unfortunately, such large sample weights led to significant problems with the mass spectrometric analyses (carbon carryover from sample to sample) such that the standard values were altered and the entire mass spectrometer run rendered unreliable. Comparisons of the same analysis between mass spectrometer runs showed large standard deviations. The leaf nitrogen data were therefore deemed to be unreliable and excluded from this study.

Statistical analyses were performed using SPSS version 22 for Mac (IBM United Kingdom Limited, PO Box 41, North Harbour, Portsmouth, Hampshire, PO6 3AU). The data were tested for normality using histograms, and Kolmogorov-Smirnoff and Shapiro-Wilk tests, and for equality of variance using Levene's tests. Most data were non-parametric, and the tests employed were Mann-Whitney, Kolmogorov-Smirnoff $\mathrm{Z}$ and Spearman's rho tests. Where data were parametric (only in the case of comparisons between grain harvested before and after maturity) independent-samples $\mathrm{t}$ tests were used, with a Welch correction in the case of leaf $\delta^{13} \mathrm{C}$. 


\section{RESULTS}

\section{Variation within leaves and panicles}

We see significant isotopic variation within a single leaf and panicle for all samples analysed (Table 2, Figure 1, Table S2). The $\delta^{13} \mathrm{C}$ values range by up to $2.1 \%$ within leaves (mean $=1.5 \%, \mathrm{n}=6)$ and $1.5 \%$ within panicles (mean=0.9\%o, $n=6)$. The $\delta^{15} \mathrm{~N}$ values range by up to $5.7 \%$ within panicles, although we note that the range in one panicle (SIT0219H) is particularly large (the ranges of the other panicles are between 0.7 and 3.3\%o: $\mathrm{n}=5$ ). There is no consistent trend in either $\delta^{13} \mathrm{C}$ or $\delta^{15} \mathrm{~N}$ value with position on the leaf or panicle - rather some leaves and panicles have values that increase, some have values that decrease and others have values both increase and decrease along the length of the leaf or panicle. Given these large ranges, samples for the studies on intra-plant, growth chamber and between-accession variation were homogenised.

\section{Variation between leaves and panicles from the same plant}

We see significant isotopic variation between leaves and between panicles in the same plant for all samples analysed (Tables 3 and 4, Figure 2, Tables S3 and S4). The $\delta^{13} \mathrm{C}$ values of different leaves within a single plant have a $2.9 \%$ range (mean $=1.4 \%, n=6$ ), while the $\delta^{13} \mathrm{C}$ values of different panicles within a single plant have a 1.6\%o range (mean $=0.8 \%, \mathrm{n}=11$ ). The $\delta^{15} \mathrm{~N}$ values of different panicles from a single plant vary by up to $3.9 \%$ o (mean=1.1\%o, $n=11)$. Given these large variations, samples for the studies on growth chamber and between-accession variation were homogenized, that is all leaves were ground together, and where a plant had multiple panicles, grains were taken from each panicle and ground together, wherever possible.

\section{Intra-line variation}

We see relatively little variation in $\delta^{13} \mathrm{C}$ and $\delta^{15} \mathrm{~N}$ values among the ten $\mathrm{S} 1$ selfed progeny of SIT0034 grown in different positions in the growth chamber (Table S5). The leaf $\delta^{13} \mathrm{C}$ values have a range of $0.5 \%$, from -14.0 to $-13.5 \%$. The grain $\delta^{13} \mathrm{C}$ values have a range of $1.2 \%$, from -13.4 to $-12.2 \%$. The grain $\delta^{15} \mathrm{~N}$ values have a range of $1.0 \%$, from 5.9 to $6.9 \%$.

\section{Variation between accessions}

In comparison to the analyses above, we see larger variations in $\delta^{13} \mathrm{C}$ and particularly in $\delta^{15} \mathrm{~N}$ values between the different accessions of Setaria italica (Table 5, Figure 3 and 4). Full information about the phenotypic characteristics and source location of these accessions are given in Table S1. The 29 accessions' leaf $\delta^{13} \mathrm{C}$ values have a range of $2.1 \%$, from -15.2 to $-13.1 \%$. Grain $\delta^{13} \mathrm{C}$ values have a range of $2.2 \%$, from 14.1 to $-12.0 \%$. The grain $\delta^{15} \mathrm{~N}$ values have a range of $6.0 \%$, from 1.8 to $7.8 \%$.

Grains harvested before and after maturity were compared in order to see if this would affect our results, although we note that sample size was small and unequal ( $n=5$ and 29, respectively). There was no difference in leaf or grain $\delta^{13} \mathrm{C}$, but the grain harvested before maturity has lower $\delta^{15} \mathrm{~N}$ values than those grains harvested after 
maturity (average $=3.3$ and 5.1\%, respectively; $\mathrm{t}=3.413, \mathrm{df}=27, \mathrm{P}=0.002)$. Subsequent statistical tests using grain $\delta^{15} \mathrm{~N}$ values were run twice (with the five immature samples included and excluded). The statistical results reported here include the immature samples and we note the one instance when the statistical conclusion of the two tests differs.

On average, grain $\delta^{13} \mathrm{C}$ values are $0.9 \%$ higher than those of leaves, although this hides a range from $2.5 \%$ higher to $0.1 \%$ lower (Figure 5). This difference is statistically significant $(\mathrm{U}=79, z=5.311, \mathrm{P}<0.001)$. In all but one accession (SIT0541), the grain $\delta^{13} \mathrm{C}$ values are higher than those of the leaves.

The data were compared with various phenotypic and geographic factors (full sample information is given in Table S1) to investigate whether any of these explain the variation seen. As regards to phenotypic factors, the intensity of green, the height of the plant and the number of panicles did not account for any significant variation in any of the isotope values. The number of days between planting and harvesting (i.e. until maturity for most of the plants) did not correlate with either leaf or grain $\delta^{13} \mathrm{C}$ value, but was moderately correlated with grain $\delta^{15} \mathrm{~N}$ value $\left(r_{s}=-0.392, \mathrm{P}=0.036\right.$; Figure S1), although we note that if the plants which were harvested before maturity are discounted then there is no correlation. Considering plant habit, there was a statistical difference between the leaf $\delta^{13} \mathrm{C}$ values of plants with a habit of 0 and plants with a habit of $1(\mathrm{Z}=1.614, \mathrm{P}=0.011)$, although the difference between the mean values is only $0.4 \%$. Leaf $\delta^{13} \mathrm{C}$ variation is strongly correlated with the number of tillers $\left(r_{s}=0.620, \mathrm{P}<0.001\right.$; Figure $\left.\mathrm{S} 2\right)$ and the number of leaves $\left(r_{s}=0.671, \mathrm{P}<0.001\right.$; Figure S3). Grain $\delta^{13} \mathrm{C}$ and $\delta^{15} \mathrm{~N}$ values were not correlated with any of the phenotypic factors. For the geographic factors, there is no correlation between isotope values and longitude or photoperiod response. There is a moderate correlation between flowering time and leaf $\delta^{13} \mathrm{C}$ value $\left(r_{s}=0.582, \mathrm{P}=0.001\right.$; Figure $\left.\mathrm{S} 4\right)$. Grain $\delta^{15} \mathrm{~N}$ values are moderately correlated with both latitude $\left(r_{s}=0.601, \mathrm{P}=0.001\right.$; Figure $\mathrm{S} 5)$ and flowering time $\left(r_{s}=0.538, \mathrm{P}=0.003\right.$; Figure $\left.\mathrm{S} 6\right)$, although we note that flowering time and latitude are also correlated $\left(r_{s}=-0.465, \mathrm{P}=0.011\right)$.

\section{DISCUSSION}

\section{Variation within leaves and panicles}

The isotopic ranges within single leaves and panicles were found to be variable in magnitude but in most cases were greater than $1 \%$, and in one case greater than $5 \%$ $\left(\delta^{15} \mathrm{~N}\right.$ value of SIT0219H grains). This led to the decision to homogenise samples for the studies on intra-plant, growth chamber and between-accession variation in order to obtain an average leaf or panicle value. The large ranges found suggest that we should be cautious in interpreting small isotopic differences between plant parts or individual plants unless they have been homogenised - differences less than $c$. 1.5\%o for leaf $\delta^{13} \mathrm{C}, c .1 \%$ for panicle $\delta^{13} \mathrm{C}$ and c. $2.5 \%$ for panicle $\delta^{15} \mathrm{~N}$ values likely represent natural variability within a leaf or panicle. No comparable data were found in the literature for millet; however, standard deviations of up to $0.6 \%$ in $\delta^{13} \mathrm{C}$ values have been found in grains taken from a single ear of bread wheat (range not reported), ${ }^{[4]}$ while different grains taken from the same ear can have a range in $\delta^{15} \mathrm{~N}$ 
value of up to $c .3 \%$. ${ }^{[72]}$ In maize, differences of $0.5 \%$ have been found in the $\delta^{13} \mathrm{C}$ values of grains taken from different positions in the ear. ${ }^{[30]}$

\section{Variation between leaves and panicles from the same plant}

We found large isotopic variability between leaves and panicles taken from a single plant. The maximum difference in the $\delta^{13} \mathrm{C}$ value of different leaves and panicles from a single plant was found to be comparable to the range of values from samples taken from within a single leaf or panicle. In contrast, the maximum difference between $\delta^{15} \mathrm{~N}$ values from different panicles of a single plant was found to be less than the variation found within a single panicle.

Consequently, samples for the studies on growth chamber and between-accession variation were homogenized in order to obtain an average plant value. Here, we were able to homogenise all of the leaves from the plant, which we would advise as best practice. We recognise, however, that this will not always be possible, but would suggest that multiple leaves must be used if a reliable average value for a plant is required. In terms of grains, we would suggest that between 20 and 30 grains are homogenised (although more maybe required if the grains are small or immature) and that these should be taken in roughly equal numbers from all of the available panicles.

The large ranges found suggest that we should be cautious in interpreting small isotopic differences between individual plants unless the samples have been homogenised, as differences less than $c .1 \%$ in panicle $\delta^{13} \mathrm{C}$ and $\delta^{15} \mathrm{~N}$, and $c .1 .5 \%$ in leaf $\delta^{13} \mathrm{C}$ values could represent natural variability within plants. No other data has been found comparing different panicles or leaves within a millet plant in the published literature; however standard deviations of up to $0.83 \%$ o have been found in $\delta{ }^{13} \mathrm{C}$ values from grains taken from different ears on single bread wheat plants (ranges not reported). ${ }^{[4]}$

\section{Intra-line variation}

While the variation seen between different plants of the same line is substantial, it is comparable to the variation within and between leaves and panicles. For leaf $\delta^{13} \mathrm{C}$ value, the range seen in SIT0034 replicates $(0.5 \%)$ is notably less than the mean range seen within a leaf $(1.5 \%)$ and less than the mean range seen between leaves from the same plant $\left(1.4 \%\right.$ ). For grain $\delta^{13} \mathrm{C}$ values, the range seen in SIT0034 replicates $(1.2 \%)$ is slightly larger than the mean range seen within a panicle $(0.9 \%$, but less than the maximum range recorded within a panicle: $1.5 \%$ ) and is larger than the mean range seen between panicles of the same plant $(0.8 \%)$. In the case of the grain $\delta^{15} \mathrm{~N}$ value, the range seen in SIT0034 replicates $(1.0 \%)$ is less than the mean range seen within a panicle $(2.6 \%)$ and comparable to the mean range seen between panicles within the same plant (1.1\%). No other data has been found for millets, however maize grown in a growth chamber had a range of $2.0 \%$ in leaf $\delta^{13} \mathrm{C}, 0.4 \%$ in grain $\delta^{13} \mathrm{C}$ and $1.6 \%$ in grain $\delta^{15} \mathrm{~N}$ values ( $\mathrm{n}=5$ for all analyses, although the genetic similarity of the plants is unclear). ${ }^{[87]}$

We therefore conclude that there is some isotopic variation between plants of the same line, either caused by genetic or positional differences. It is not possible to 
distinguish between these two factors without using isogenic lines, which was beyond the scope of this study. Further, we did not investigate true within-accession variation in this study, which would require sowing multiple grains from each of the original accession samples. This was not practicable here due to growth chamber space limitations. The isotopic effect of within-line variation is likely to be swamped by intra-plant variation.

We infer that differences of up to $1 \%$ could result from intra-plant or intra-line variability and this baseline noise should be taken into consideration in isotopic studies.

\section{Variation between accessions}

First, we note that the $\delta^{13} \mathrm{C}$ values (-15.2 to $-12.0 \%$ ) observed here are typical for $\mathrm{C}_{4}$ plants, ${ }^{[22]}$ while the $\delta^{15} \mathrm{~N}$ values $(1.8$ to $7.8 \%$ ) are in some cases notably higher than would be expected for a non-leguminous plant. ${ }^{[88]}$

The range seen across accessions is approximately $2 \%$ in $\delta^{13} \mathrm{C}$ values (leaves and grains) and 6\%o in $\delta^{15} \mathrm{~N}$ values for grains (Figures 3 and 4). Even if the samples had not been homogenized, these values are larger than would be expected given the typical variations within leaves or panicles, between leaves and panicles or due to intra-line differences. We therefore suggest that these data reflect real isotopic variation that arises due to genetic differences between accessions, which could be tested by analysis of their genetic diversity.

In field trials, 13 different varieties of Setaria italica grown on the same plot have found a $c .1 \%$ range of $\delta^{13} \mathrm{C}$ values in both grains and leaves. ${ }^{[33]}$ The data presented here show that different accessions of Setaria italica grown under the same conditions can have a $2 \%$ range in $\delta^{13} \mathrm{C}$ values. Given that $\mathrm{C}_{4}$ plants are expected to show little isotopic variation within and between species in $\delta^{13} \mathrm{C}$ values, this $2 \%$ range is significant. In terms of archaeological interpretation for palaeodiet, a $2 \%$ difference between two people or groups of people would be seen as a real difference in subsistence practice. However, here we have shown that this difference may not reflect the amount of millet or other $\mathrm{C}_{4}$ plant consumed, but rather could relate to the variety of that plant.

The intraspecific variation found has wider implications beyond palaeodietary studies. For example, $\mathrm{C}_{4}$ plant $\delta^{13} \mathrm{C}$ values are sometimes used to study the isotopic composition of atmospheric $\mathrm{CO}_{2}$, because they are relatively insensitive to environmental conditions. The data presented here suggest that it is important to ensure that the same variety is studied throughout the period or area under study, and to consider the variation within and between plants.

In terms of $\delta^{15} \mathrm{~N}$ values, both the high values and the $6 \%$ range between accessions are surprising, and have several implications for archaeology. Firstly, in non-arid areas, plant $\delta^{15} \mathrm{~N}$ values as high as $8 \%$ would typically be interpreted as clear evidence for manuring, ${ }^{[3,72]}$ while in arid areas such high $\delta^{15} \mathrm{~N}$ values would likely be seen as a reflection of the limited precipitation. ${ }^{[75,89]}$ The data presented here indicate that high $\delta{ }^{15} \mathrm{~N}$ values do not necessarily relate to either of these factors, but may 
simply relate to the variety of the species studied. Therefore, when humans or animals from different sites are compared, differences in $\delta^{15} \mathrm{~N}$ values may relate to the proportion of animal protein consumed, differences in the $\delta^{15} \mathrm{~N}$ value of the soil due to manuring, differences in aridity between sites, or simply due to difference in the variety of millet being consumed.

Secondly, the large range has significant implications to the interpretation of the proportion of animal protein consumed. A single trophic level is typically seen as being represented by a $3-5 \%$ increase in $\delta^{15} \mathrm{~N}$ value. The foxtail millet accessions analysed here, however, have a range greater than that of a single trophic level, and in some cases $\delta^{15} \mathrm{~N}$ that are similar to those observed in herbivorous animals. If plant values are not obtained in palaeodietary studies there is the potential for erroneous interpretation of human $\delta^{15} \mathrm{~N}$ values, particularly if any animals sampled did not consume millet (or other plants with high $\delta^{15} \mathrm{~N}$ values). In this scenario, it is entirely possible that the millet and the animals would have similar $\delta^{15} \mathrm{~N}$ values. This would make it impossible to distinguish between human diets with a high proportion of animal protein and human diets containing little or no animal protein, on the basis of nitrogen isotope data alone, as the nitrogen contained in the plant and animal foods have similar $\delta^{15} \mathrm{~N}$ values. This finding also has similar implications for the interpretation of data from omnivorous animals and for comparisons between people in a population with access to different resources.

The typical $0.9 \%$ difference between grains and leaves (Figure 5) is comparable to the $0.8 \%$ difference found in field trials. ${ }^{[33]}$ This consistent offset is likely to have an impact upon archaeological research, particularly if humans consume the grains and animals the stems and leaves, as has been suggested for the Iron Age site of Danebury in the $\mathrm{UK}^{[7]}$ and in some contemporary communities. ${ }^{[13]}$

Phenotypic and geographical factors were compared with the isotope values of the accessions in order to investigate why the accessions had different values. In general, there was little correlation between the phenotypic factors (days until maturity, plant habit, intensity of green, the number of tillers, the height of the plant, the number of panicles and the number of leaves) and the isotope values. Nevertheless, the number of leaves and tillers does correlate with leaf $\delta^{13} \mathrm{C}$ values, and plants with an upright habit were statistically different in leaf $\delta^{13} \mathrm{C}$ values from plants with a semi-bushy habit. In terms of the geographical factors, while longitude of origin did not correlate with any of the isotope values, flowering time accounts for some of the variation in leaf $\delta^{13} \mathrm{C}$ values, while latitude and flowering time account for some of the variation in grain $\delta^{15} \mathrm{~N}$ values. The grains harvested before maturity have lower $\delta^{15} \mathrm{~N}$ values than the other grains (although their sample size was small). It is unclear if this is related to their immature status or the length of time until flowering. It is likely that some of the variation between accessions is related to plant adaptation to environmental conditions, such as temperature and daylength.

\section{CONCLUSION}

Here we have shown that there is significant isotope variability in foxtail millet plants, within single leaves and panicles and between leaves and panicles in the same plant. This variability must be considered when undertaking plant isotope studies. 
Using homogenised samples, we have shown that there is substantial range in isotope values among Setaria italica accessions, approximately $2 \%$ in $\delta^{13} \mathrm{C}$ and $6 \%$ in $\delta^{15} \mathrm{~N}$ values. We have also shown that there is an isotopic offset between $\delta^{13} \mathrm{C}$ values of grains and leaves of, on average, $0.9 \%$. These values are large enough to affect archaeological interpretations, particularly in the case of the variability in $\delta^{15} \mathrm{~N}$ values between accessions which represents more than a trophic level. It is clear that without obtaining appropriately representative plant isotope values, which factor in the possibility of substantial isotope variability, isotope studies run the risk of misinterpreting human and animal data, with potentially significant implications for our understanding of the past.

\section{Acknowledgements}

The authors are grateful to Catherine Kneale and James Rolfe (University of Cambridge) for their help with isotopic analysis, to Rob Brett (Sainsbury Laboratory, University of Cambridge) for his help with access and use of the chamber and to Ian Mackay (NIAB) for help with experimental design. We thank the National Institute of Agrobiological Sciences, Japan (NIAS); Leibniz-Institut für Pflanzengenetik und Kulturpflanzenforschung, Gatersleben, Germany (IPK Gatersleben); the N.I. Vavilov Institute of Plant Genetic Resources, Russia (VIR); The International Crops Research Institute for the Semi-Arid Tropics, India (ICRISAT) and the United States Department of Agriculture Agricultural Research Centre (USDA-ARS) for providing plant material. We wish to thank the European Research Council for financial support. We are also grateful to the three anonymous reviewers for their useful comments on the manuscript.

\section{REFERENCES}

[1] M. Aguilera, J. L. Araus, J. Voltas, M. O. Rodriguez-Ariza, F. Molina, N. Rovira, R. Buxo, J. P. Ferrio. Stable carbon and nitrogen isotopes and quality traits of fossil cereal grains provide clues on sustainability at the beginnings of Mediterranean agriculture. Rapid Commun. Mass Spectrom. 2008, 22, 1653.

[2] J. L. Araus, A. Febrero, M. Catala, M. Molist, J. Voltas, I. Romagosa. Crop water availability in early agriculture: Evidence from carbon isotope discrimination of seeds from a tenth millennium BP site on the Euphrates. Global Change Biology 1999, 5, 201.

[3] A. Bogaard, R. Fraser, T. H. E. Heaton, M. Wallace, P. Vaiglova, M. Charles, G. Jones, R. P. Evershed, A. K. Styring, N. H. Andersen, R.-M. Arbogast, L. Bartosiewic, A. Gardeisen, M. Kanstrup, U. Maier, E. Marinova, L. Ninov, M. Schaefer, E. Stephan. Crop manuring and intensive land management by Europe's first farmers. Proc. Natl. Acad. Sci. U. S. A. 2013, 110, 12589.

[4] T. H. E. Heaton, G. Jones, P. Halstead, T. Tsipropoulos. Variations in the ${ }^{13} \mathrm{C} /{ }^{12} \mathrm{C}$ ratios of modern wheat grain, and implications for interpreting data from Bronze Age Assiros Toumba, Greece. J. Archaeol. Sci. 2009, 36, 2224.

[5] L. A. Cernusak, N. Ubierna, K. Winter, J. A. M. Holtum, J. D. Marshall, G. D. Farquhar. Environmental and physiological determinants of carbon isotope discrimination in terrestrial plants. New Phytol. 2013, 200, 950.

[6] P. Högberg. ${ }^{15} \mathrm{~N}$ natural abundance as a possible marker of the ectomycorrhizal habit of trees in mixed African woodlands. New Phytol. 1990, 115,483 . 
[7] E. Lightfoot, R. E. Stevens. Stable isotope investigations of charred barley (Hordeum vulgare) and wheat (Triticum spelta) grains from Danebury Hillfort: implications for palaeodietary reconstructions. J. Archaeol. Sci. 2012, 39, 656.

[8] K. Rachie. The Millets: Importance, Utilisation and Outlook, International Crops Research Institute for the Semi-arid Tropics, Hyderabad, 1975.

[9] M. Rao, Inaugural address, in Small Millets in Global Agriculture (Eds.: A. Seetharam, K. Riley, G. Harinarayana), Oxford \& IBN Publishing, New Delhi, 1989.

[10] M. Joshi. The Textbook of Field Crops, PHI Learning Private Limited, Delhi, 2015.

[11] E. Lightfoot, X. Liu, M. K. Jones. Why move starchy cereals? A review of the isotopic evidence for prehistoric millet consumption across Eurasia. World Archaeology 2013, 45, 574.

[12] H. V. Hunt, M. V. Linden, X. Liu, G. Motuzaite-Matuzeviciute, S. Colledge, M. K. Jones. Millets across Eurasia: Chronology and context of early records of the genera Panicum and Setaria from archaeological sites in the Old World. Vegetation History and Archaeobotany 2008, 17, S5.

[13] A. Moreno-Larrazabal, A. Teira-Brion, I. Sopelana-Salcedo, A. ArranzOtaegui, L. Zapata. Ethnobotany of millet cultivation in the north of the Iberian Peninsula. Vegetation History and Archaeobotany 2015, 24, 541.

[14] Z. Zhao. New Archaeobotanic data for the study of the origins of agriculture in China. Current Anthropology 2011, 52, S295.

[15] C. Wang, G. Jia, H. Zhi, Z. Niu, Y. Chai, W. Li, Y. Wang, H. Li, P. Lu, B. Zhao, X. Diao. Genetic diversity and population structure of Chinese foxtail millet [Setaria italica (L.) Beauv.] Landraces. G3. Genes. Genomes. Genetics 2012, 2, 769.

[16] J. L. Bennetzen, J. Schmutz, H. Wang, R. Percifield, J. Hawkins, A. C. Pontaroli, M. Estep, L. Feng, J. N. Vaughn, J. Grimwood, J. Jenkins, K. Barry, E. Lindquist, U. Hellsten, S. Deshpande, X. Wang, X. Wu, T. Mitros, J. Triplett, X. Yang, C.-Y. Ye, M. Mauro-Herrera, L. Wang, P. Li, M. Sharma, R. Sharma, P. C. Ronald, O. Panaud, E. A. Kellogg, T. P. Brutnell, A. N. Doust, G. A. Tuskan, D. Rokhsar, K. M. Devos. Reference genome sequence of the model plant Setaria. Nat Biotech 2012, 30, 555.

[17] G. Zhang, X. Liu, Z. Quan, S. Cheng, X. Xu, S. Pan, M. Xie, P. Zeng, Z. Yue, W. Wang, Y. Tao, C. Bian, C. Han, Q. Xia, X. Peng, R. Cao, X. Yang, D. Zhan, J. Hu, Y. Zhang, H. Li, H. Li, N. Li, J. Wang, C. Wang, R. Wang, T. Guo, Y. Cai, C. Liu, H. Xiang, Q. Shi, P. Huang, Q. Chen, Y. Li, J. Wang, Z. Zhao, J. Wang. Genome sequence of foxtail millet (Setaria italica) provides insights into grass evolution and biofuel potential. Nat Biotech 2012, 30, 549.

[18] R. E. M. Hedges. Isotopes and red herrings: Comments on Milner et al. and Lidén et al. Antiquity 2004, 78, 34.

[19] G. D. Farquhar, M. H. Oleary, J. A. Berry. On the relationship between carbon isotope discrimination and the inter-cellular carbon-dioxide concentration in leaves. Aust. J. Plant Physiol. 1982, 9, 121.

[20] T. H. E. Heaton. Spatial, species, and temporal variations in the ${ }^{13} \mathrm{C} /{ }^{12} \mathrm{C}$ ratios of $\mathrm{C}_{3}$ plants: Implications for palaeodiet studies. J. Archaeol. Sci. 1999, 26, 637.

[21] S. Ambrose, Isotopic analysis of palaeodiets: methodological and interpretative considerations, in Investigations of Ancient Human Tissue: 
Chemical Analyses in Anthropology (Ed.: M. Sandford), Gordan and Breach Scientific, New York, 1993, pp. 59.

[22] M. H. O'Leary. Carbon isotopes in photosynthesis. Bioscience 1988, 38, 328.

[23] G. D. Farquhar. On the nature of carbon isotope discrimination in $\mathrm{C}_{4}$ species. Aust. J. Plant Physiol. 1983, 10, 205.

[24] S. Henderson, S. von Caemmerer, G. D. Farquhar, L. Wade, G. Hammer. Correlation between carbon isotope discrimination and transpiration efficiency in lines of the $\mathrm{C}_{4}$ species Sorghum bicolor in the glasshouse and the field. Aust. J. Plant Physiol. 1998, 25, 111.

[25] A. B. Cousins, M. R. Badger, S. von Caemmerer. $\mathrm{C}_{4}$ photosynthetic isotope exchange in NAD-ME- and NADP-ME-type grasses. J. Exp. Bot. 2008, 59, 1695.

[26] P. W. Hattersley. $\delta^{13} \mathrm{C}$ Values of $\mathrm{C}_{4}$ Types in Grasses. Aust. J. Plant Physiol. 1982, 9, 139.

[27] J. Ehleringer, O. Björkman. Quantum yields for $\mathrm{CO}_{2}$ uptake in $\mathrm{C}_{3}$ and $\mathrm{C}_{4}$ plants: dependence on temperature, $\mathrm{CO}_{2}$ and $\mathrm{O}_{2}$ concentration. Plant Physiol. 1977, 59, 86.

[28] J. R. Ehleringer, R. K. Monson. Evolutionary and ecological aspects of photosynthetic pathway variation. Annu. Rev. Ecol. Syst. 1993, 24, 411.

[29] B. I. Hesla, L. L. Tieszen, S. K. Imbamba. A systematic survey of $\mathrm{C}_{3}$ and $\mathrm{C}_{4}$ photosynthesis in the cyperaceae of Kenya, East-Africa. Photosynthetica 1982, 16, 196.

[30] L. L. Tieszen, T. Fagre. Carbon isotopic variability in modern and archaeological maize. J. Archaeol. Sci. 1993, 20, 25.

[31] K. T. Hubick, G. L. Hammer, G. D. Farquhar, L. J. Wade, S. Voncaemmerer, $\mathrm{S}$. A. Henderson. Carbon isotope discrimination varies genetically in $\mathrm{C}_{4}$ species. Plant Physiol. 1990, 92, 534.

[32] R. Ohsugi, M. Samejima, N. Chonan, T. Murata. $\delta^{13} \mathrm{C}$ values and the occurrence of suberized lamellae in some panicum species. Ann. Bot. 1988, $62,53$.

[33] C.-B. An, W. Dong, H. Li, P. Zhang, Y. Zhao, X. Zhao, S.-Y. Yu. Variability of the stable carbon isotope ratio in modern and archaeological millets: evidence from northern China. J. Archaeol. Sci. 2015, 53, 316.

[34] N. Buchmann, J. R. Brooks, K. D. Rapp, J. R. Ehleringer. Carbon isotope composition of $\mathrm{C}_{4}$ grasses is influenced by light and water supply. Plant, Cell Environ. 1996, 19, 392.

[35] J. Kromdijk, H. E. Schepers, F. Albanito, N. Fitton, F. Carroll, M. B. Jones, J. Finnan, G. J. Lanigan, H. Griffiths. Bundle sheath leakiness and light limitation during $\mathrm{C}_{4}$ leaf and canopy $\mathrm{CO}_{2}$ uptake. Plant Physiol. 2008, 148, 2144.

[36] N. Ubierna, W. Sun, D. M. Kramer, A. B. Cousins. The efficiency of $C_{4}$ photosynthesis under low light conditions in Zea mays, Miscanthus $\mathrm{X}$ giganteus and Flaveria bidentis. Plant, Cell Environ. 2013, 36, 365.

[37] W. G. Liu, X. H. Feng, Y. F. Ning, Q. L. Zhang, Y. N. Cao, Z. S. An. $\delta^{13} \mathrm{C}$ variation of $\mathrm{C}_{3}$ and $\mathrm{C}_{4}$ plants across an Asian monsoon rainfall gradient in arid northwestern China. Global Change Biology 2005, 11, 1094.

[38] O. Ghannoum, S. von Caemmerer, J. P. Conroy. The effect of drought on plant water use efficiency of nine NAD-ME and nine NADP-ME Australian $\mathrm{C}_{4}$ grasses. Funct. Plant Biol. 2002, 29, 1337. 
[39] W. D. Bowman, K. T. Hubick, S. Voncaemmerer, G. D. Farquhar. Short-term changes in leaf carbon isotope discrimination in salt-stressed and waterstressed $\mathrm{C}_{4}$ grasses. Plant Physiol. 1989, 90, 162.

[40] F. C. Meinzer, Z. Plaut, N. Z. Saliendra. Carbon-isotope discrimination, gasexchange, and growth of sugarcane cultivars under salinity. Plant Physiol. 1994, 104, 521.

[41] G. Wang, J. Han, A. Faiia, W. Tan, W. Shi, X. Liu. Experimental measurements of leaf carbon isotope discrimination and gas exchange in the progenies of Plantago depressa and Setaria viridis collected from a wide altitudinal range. Physiol. Plant. 2008, 134, 64.

[42] R. J. Swap, J. N. Aranibar, P. R. Dowty, W. P. Gilhooly III, S. A. Macko. Natural abundance of ${ }^{13} \mathrm{C}$ and ${ }^{15} \mathrm{~N}$ in $\mathrm{C}_{3}$ and $\mathrm{C}_{4}$ vegetation of southern Africa: Patterns and implications. Global Change Biology 2004, 10, 350.

[43] G. Gleixner, H. J. Danier, R. A. Werner, H. L. Schmidt. Correlations between the ${ }^{13} \mathrm{C}$ content of primary and secondary plant-products in different cell compartments and that in decomposing basidiomycetes. Plant Physiol. 1993, $102,1287$.

[44] J. A. Lowdon. Isotopic fractionation in corn. Radiocarbon 1969, 11, 391.

[45] T. Desjardins, F. Andreux, B. Volkoff, C. C. Cerri. Organic-carbon and ${ }^{13} \mathrm{C}$ contents in soils and soil size-fractions, and their changes due to deforestation and pasture installation in eastern Amazonia. Geoderma 1994, 61, 103.

[46] C. Trouve, A. Mariotti, D. Schwartz, B. Guillet. Soil organic-carbon dynamics under eucalyptus and pinus planted on savannas in the Congo. Soil Biol. Biochem. 1994, 26, 287.

[47] M. Schweizer, J. Fear, G. Cadisch. Isotopic $\left({ }^{13} \mathrm{C}\right)$ fractionation during plant residue decomposition and its implications for soil organic matter studies. Rapid Commun. Mass Spectrom. 1999, 13, 1284.

[48] A. Spain, R. LeFeuvre. Stable C and N isotope values of selected components of a tropical Australian sugarcane ecosystem. Biol. Fertil. Soils 1997, 24, 118.

[49] J. W. Collister, G. Rieley, B. Stern, G. Eglinton, B. Fry. Compound-specific $\delta^{13} \mathrm{C}$ analyses of leaf lipids from plants with differing carbon-dioxide metabolisms. Org. Geochem. 1994, 21, 619.

[50] Y. Chikaraishi, H. Naraoka. Organic hydrogen-carbon isotope signatures of terrestrial higher plants during biosynthesis for distinctive photosynthetic pathways. Geochem. J. 2001, 35, 451.

[51] R. Benner, M. L. Fogel, E. K. Sprague, R. E. Hodson. Depletion of ${ }^{13} \mathrm{C}$ in lignin and its implications for stable carbon isotope studies. Nature 1987, 329, 708.

[52] T. C. O'Connell, R. E. M. Hedges. Investigations into the effect of diet on modern human hair isotopic values. Am. J. Phys. Anthropol. 1999, 108, 409.

[53] H. Bocherens, D. Drucker. Trophic level isotopic enrichment of carbon and nitrogen in bone collagen: Case studies from recent and ancient terrestrial ecosystems. International Journal of Osteoarchaeology 2003, 13, 46.

[54] R. E. M. Hedges, L. M. Reynard. Nitrogen isotopes and the trophic level of humans in archaeology. J. Archaeol. Sci. 2007, 34, 1240.

[55] M. I. Makarov. The nitrogen isotopic composition in soils and plants: its use in environmental studies (a review). Eurasian Soil Sci. 2009, 42, 1335.

[56] D. Robinson. $\delta^{15} \mathrm{~N}$ as an integrator of the nitrogen cycle. Trends in Ecology and Evolution 2001, 16, 153. 
[57] A. T. Austin, P. M. Vitousek. Nutrient dynamics on a precipitation gradient in Hawai'i. Oecologia 1998, 113, 519.

[58] L. L. Handley, A. T. Austin, D. Robinson, C. M. Scrimgeour, J. A. Raven, T. H. E. Heaton, S. Schmidt, G. R. Stewart. The ${ }^{15} \mathrm{~N}$ - natural abundance $\left(\delta^{15} \mathrm{~N}\right)$ of ecosystem samples reflects measures of water availability. Aust. J. Plant Physiol. 1999, 26, 185.

[59] D. L. Brenner, R. Amundson, W. T. Baisden, C. Kendall, J. Harden. Soil N and ${ }^{15} \mathrm{~N}$ variation with time in a California annual grassland ecosystem. Geochim. Cosmochim. Acta 2001, 65, 4171.

[60] S. X. Chang, L. L. Handley. Site history affects soil and plant ${ }^{15} \mathrm{~N}$ natural abundances (delta N-15) in forests of northern Vancouver Island, British Columbia. Functional Ecology 2000, 14, 273.

[61] R. Amundson, A. T. Austin, E. A. G. Schuur, K. Yoo, V. Matzek, C. Kendall, A. Uebersax, D. Brenner, W. T. Baisden. Global patterns of the isotopic composition of soil and plant nitrogen. Global Biogeochem. Cycles 2003, 17, 11 .

[62] J.-W. Van Groenigen, C. Van Kessel. Salinity-induced patterns of natural abundance carbon-13 and nitrogen-15 in plant and soil. Soil Sci. Soc. Am. J. 2002, 66, 489.

[63] W. J. Choi, H. M. Ro, E. A. Hobbie. Patterns of natural ${ }^{15} \mathrm{~N}$ in soils and plants from chemically and organically fertilized uplands. Soil Biol. Biochem. 2003, $35,1493$.

[64] X.-z. Liu, G. Wang. Measurements of nitrogen isotope composition of plants and surface soils along the altitudinal transect of the eastern slope of Mount Gongga in southwest China. Rapid Commun. Mass Spectrom. 2010, 24, 3063.

[65] L. L. Handley, J. A. Raven. The use of natural abundance of nitrogen isotopes in plant physiology and ecology. Plant, Cell Environ. 1992, 15, 965.

[66] K. Nadelhoffer, G. Shaver, B. Fry, A. Giblin, L. Johnson, R. McKane. ${ }^{15} \mathrm{~N}$ natural abundances and N use by tundra plants. Oecologia 1996, 107, 386.

[67] M. Unkovich. Isotope discrimination provides new insight into biological nitrogen fixation. New Phytol. 2013, 198, 643.

[68] A. Michelsen, C. Quarmby, D. Sleep, S. Jonasson. Vascular plant ${ }^{15} \mathrm{~N}$ natural abundance in heath and forest tundra ecosystems is closely correlated with presence and type of mycorrhizal fungi in roots. Oecologia 1998, 115, 406.

[69] R. Virginia, C. Delwiche. Natural ${ }^{15} \mathrm{~N}$ abundance of presumed $\mathrm{N}_{2}$-fixing and non $\mathrm{N}_{2}$-fixing plants from selected ecosystems. Oecologia 1982, 54, 317.

[70] D. Robinson, L. L. Handley, C. M. Scrimgeour, D. C. Gordon, B. P. Forster, R. P. Ellis. Using stable isotope natural abundances $\left(\delta^{15} \mathrm{~N}\right.$ and $\left.\delta^{13} \mathrm{C}\right)$ to integrate the stress responses of wild barley (Hordeum spontaneum C. Koch.) genotypes. J. Exp. Bot. 2000, 51, 41.

[71] L. L. Handley, D. Robinson, B. P. Forster, R. P. Ellis, C. M. Scrimgeour, D. C. Gordon, E. Nevo, J. A. Raven. Shoot $\delta^{15} \mathrm{~N}$ correlates with genotype and salt stress in barley. Planta 1997, 201, 100.

[72] A. Bogaard, T. H. E. Heaton, P. Poulton, I. Merbach. The impact of manuring on nitrogen isotope ratios in cereals: archaeological implications for reconstruction of diet and crop management practices. J. Archaeol. Sci. 2007, 34, 335.

[73] R. D. Evans, A. J. Bloom, S. S. Sukrapanna, J. R. Ehleringer. Nitrogen isotope composition of tomato (Lycopersicon esculentum Mill. cv. T-5) grown under ammonium or nitrate nutrition. Plant, Cell Environ. 1996, 19, 1317. 
[74] T. Yoneyama, F. Tanaka. Natural abundance of ${ }^{15} \mathrm{~N}$ in nitrate, ureides, and amino acids from plant tissues. Soil Sci. Plant Nutr. 1999, 45, 751.

[75] T. H. E. Heaton, J. C. Vogel, G. Vonlachevallerie, G. Collett. Climatic influence on the isotopic composition of bone nitrogen. Nature 1986, 322, 822.

[76] J. Sealy. Stable carbon and nitrogen isotope ratios and coastal diets in the Later Stone Age of South Africa: A comparison and critical analysis of two data sets. Ancient Biomol. 1997, 1, 131.

[77] X. Liu, E. Lightfoot, T. C. O'Connell, H. Wang, S. Li, L. Zhou, Y. Hu, G. Motuzaite-Matuzeviciute, M. K. Jones. From necessity to choice: dietary revolutions in west China in the second millennium BC. World Archaeology 2014, 46, 661 .

[78] M. M. Ma, G. H. Dong, E. Lightfoot, H. Wang, X. Y. Liu, X. Jia, K. R. Zhang, F. H. Chen. Stable isotope analysis of human and faunal remains in the Western Loess Plateau, approximately 2000 cal bc. Archaeometry 2014, 56, 237.

[79] R. A. Fraser, A. Bogaard, T. Heaton, M. Charles, G. Jones, B. T. Christensen, P. Halstead, I. Merbach, P. R. Poulton, D. Sparkes, A. K. Styring. Manuring and stable isotope ratios in cereals and pulses: towards a new archaeobotanical approach to the inference of land use and dietary practices. J. Archaeol. Sci. 2011, 38, 2790.

[80] I. Raimanová, J. Haberle. The effects of differentiated water supply after anthesis and nitrogen fertilization on $\delta^{15} \mathrm{~N}$ of wheat grain. Rapid Commun. Mass Spectrom. 2010, 24, 261.

[81] C. C. Li. Inheritance of the basic vegetative phase and photoperiod sensitivity in rice (Oryza sativa L.). Thesis submitted to University of the Philippines (Los Baños, Philippines), 1966.

[82] N. D. Coles, M. D. McMullen, P. J. Balint-Kurti, R. C. Pratt, J. B. Holland. Genetic control of photoperiod sensitivity in maize revealed by joint multiple population analysis. Genetics 2010, 184, 799.

[83] C. Wang, G. Jia, H. Zhi, Z. Niu, Y. Chai, W. Li, Y. Wang, H. Li, P. Lu, B. Zhao, X. Diao. Genetic diversity and population structure of Chinese foxtail millet Setaria italica (L.) Beauv. landraces. G3-Genes Genomes Genetics 2012, 2, 769.

[84] H. Craig. Isotopic standards for carbon and oxygen and correction factors for mass-spectrometric analysis of carbon dioxide. Geochim. Cosmochim. Acta 1957, 12, 133.

[85] A. Mariotti. Atmospheric nitrogen is a reliable standard for natural ${ }^{15} \mathrm{~N}$ abundance measurements. Nature 1983, 303, 685.

[86] J. Hoefs. Stable Isotope Geochemistry, Springer Verlag, Heidelberg, 2004.

[87] P. Szpak, F. J. Longstaffe, J.-F. Millaire, C. D. White. Stable isotope biogeochemistry of seabird guano fertilization: results from growth chamber studies with maize (Zea mays). PLoS One 2012, 7.

[88] N. Van Der Merwe, Light stable isotopes and the reconstruction of prehistoric diets, in New Developments in Archaeological Science: A Joint Symposium of the Royal Society and the British Academy, February 1991 (Ed.: A. Pollard), Oxford University Press, Oxford, 1992.

[89] J. C. Sealy, N. J. Vandermerwe, J. A. L. Thorp, J. L. Lanham. Nitrogen isotopic ecology in southern-Africa - implications for environmental and dietary tracing. Geochim. Cosmochim. Acta 1987, 51, 2707 


\section{FIGURES}

Figure 1a: Comparison of isotope values for different points within a leaf or panicle: (a) $\delta^{13} \mathrm{C}$ values within a leaf; (b) $\delta^{13} \mathrm{C}$ values within a panicle; and (c) $\delta^{15} \mathrm{~N}$ values within a panicle

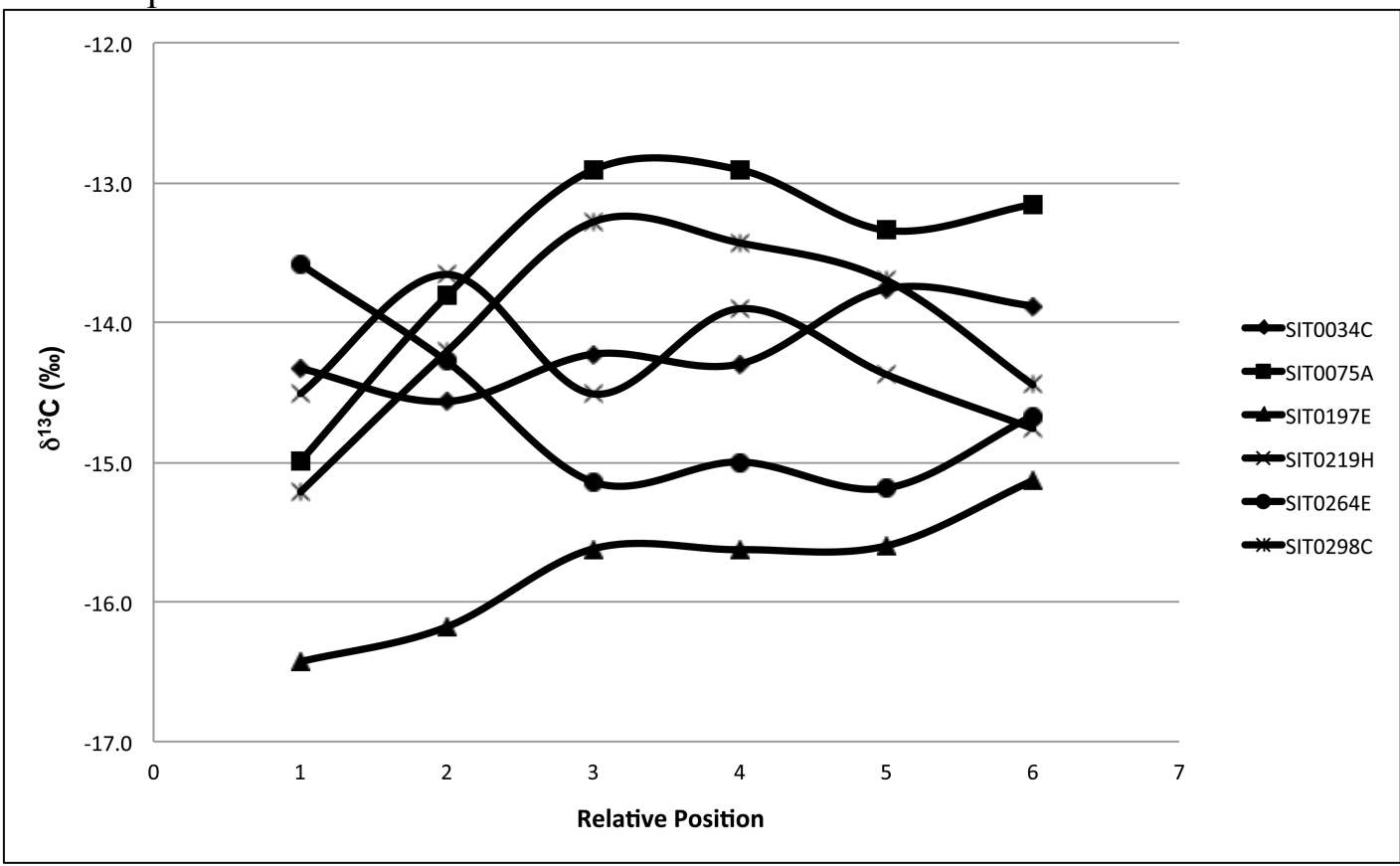

Figure 1b: Comparison of isotope values for different points within a leaf or panicle: (a) $\delta^{13} \mathrm{C}$ values within a leaf; (b) $\delta^{13} \mathrm{C}$ values within a panicle; and (c) $\delta^{15} \mathrm{~N}$ values within a panicle

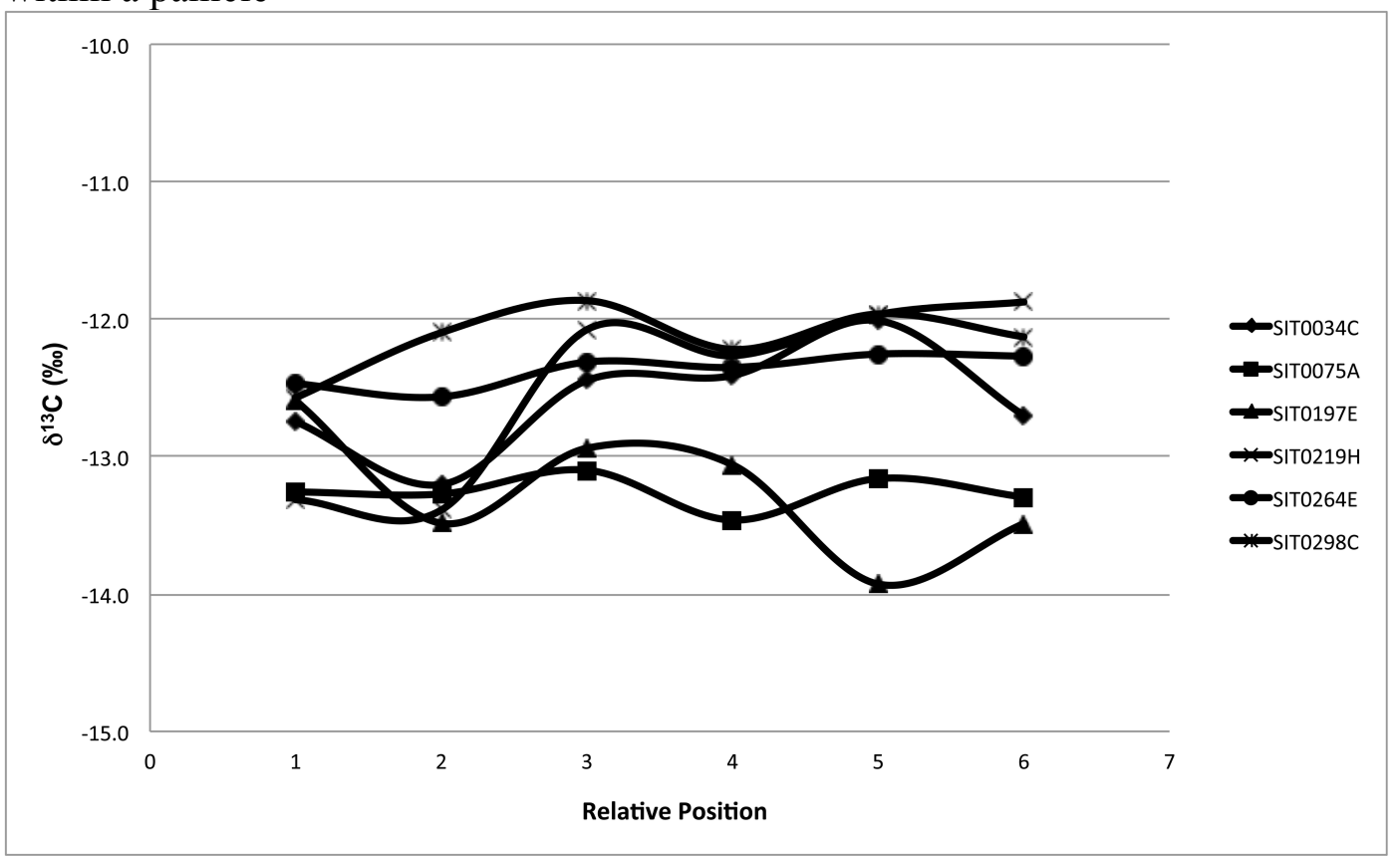


Figure 1c: Comparison of isotope values for different points within a leaf or panicle: (a) $\delta^{13} \mathrm{C}$ values within a leaf; (b) $\delta^{13} \mathrm{C}$ values within a panicle; and (c) $\delta^{15} \mathrm{~N}$ values within a panicle

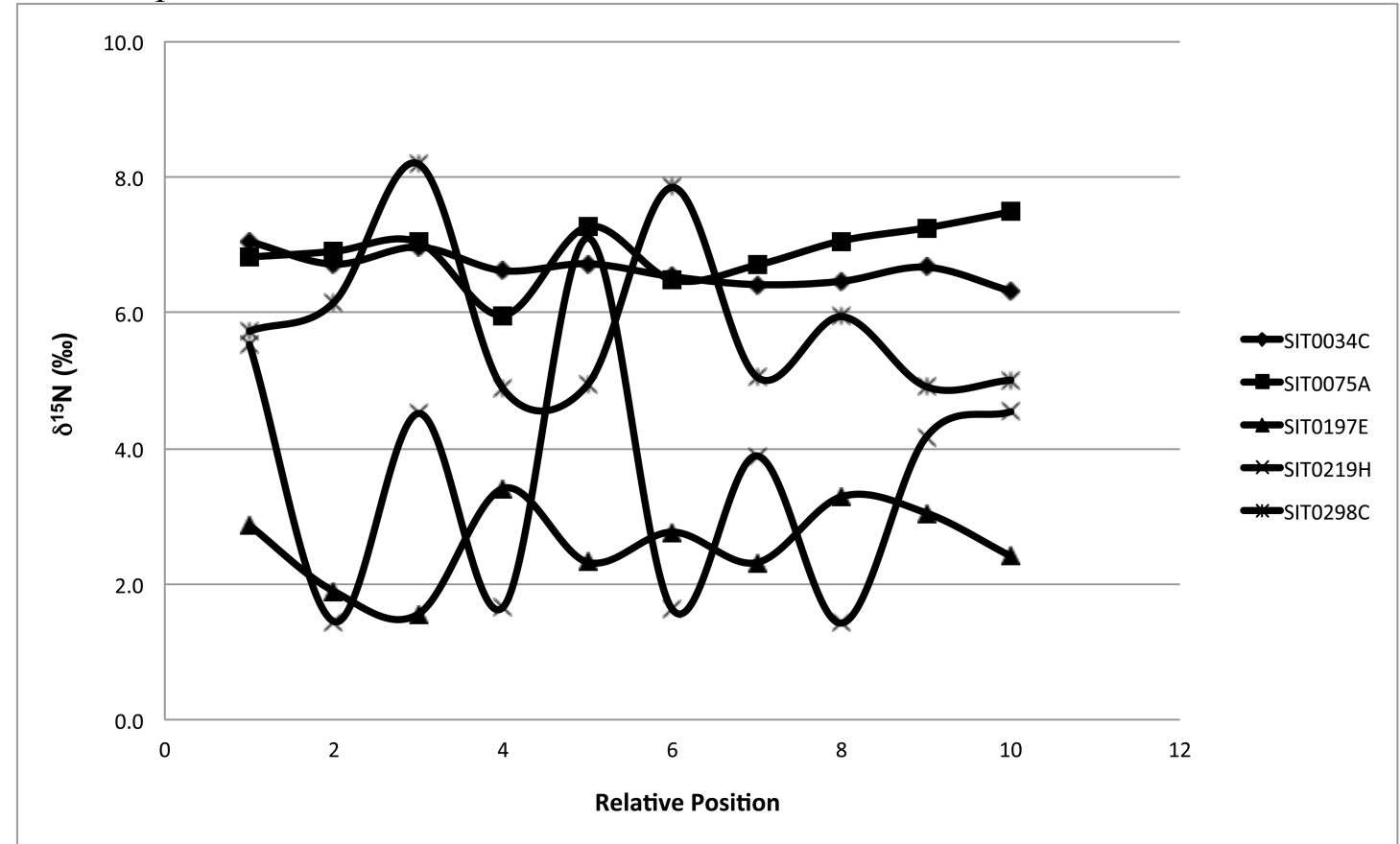

Figure 2a: Boxplot showing isotope values of different leaves and panicles from individual plants: (a) $\delta^{13} \mathrm{C}$ values from leaves; (b) $\delta^{13} \mathrm{C}$ values from panicles; and (c) $\delta^{15} \mathrm{~N}$ values from panicles.

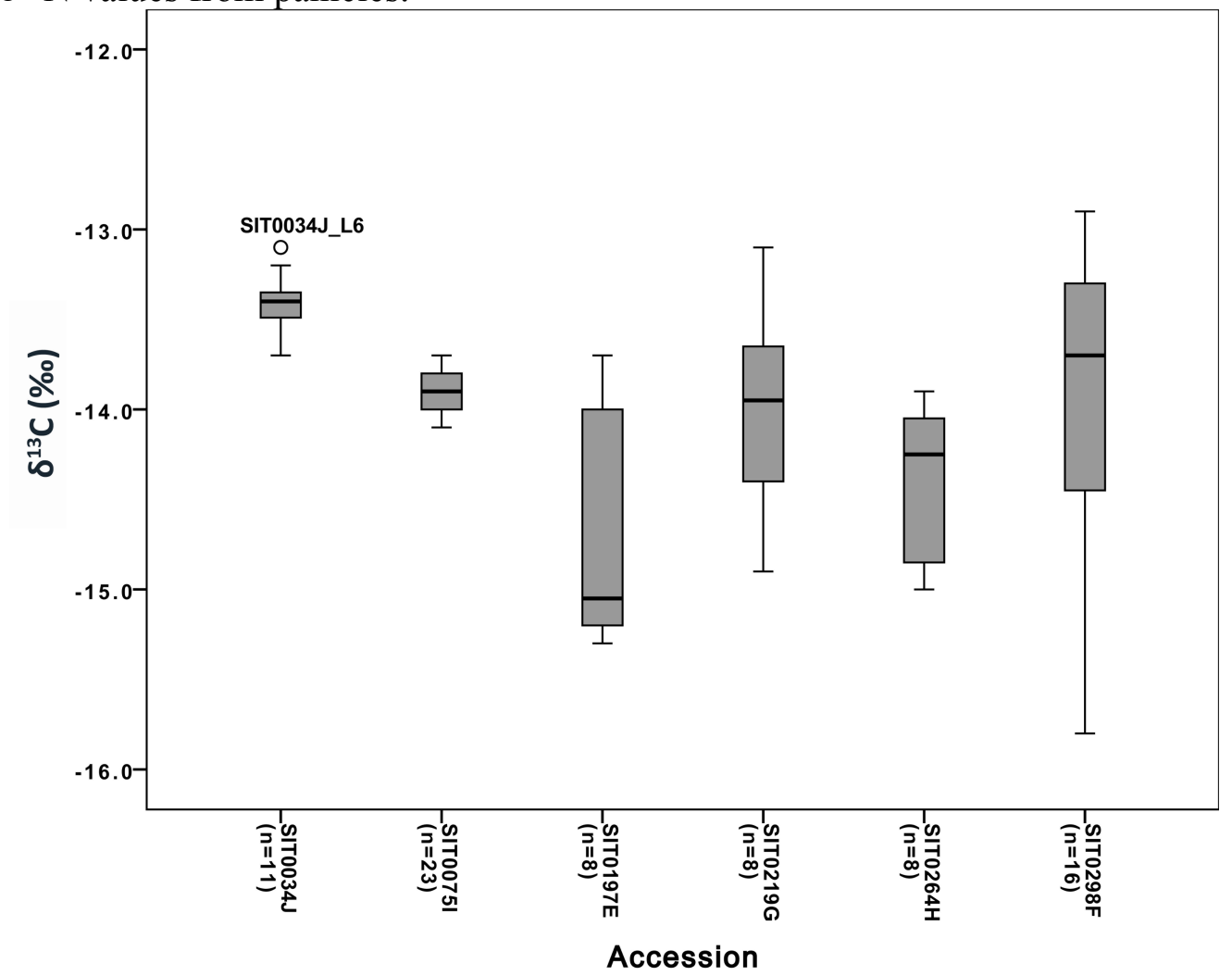


Figure 2b: Boxplot showing isotope values of different leaves and panicles from individual plants: (a) $\delta{ }^{13} \mathrm{C}$ values from leaves; (b) $\delta^{13} \mathrm{C}$ values from panicles; and (c) $\delta^{15} \mathrm{~N}$ values from panicles.

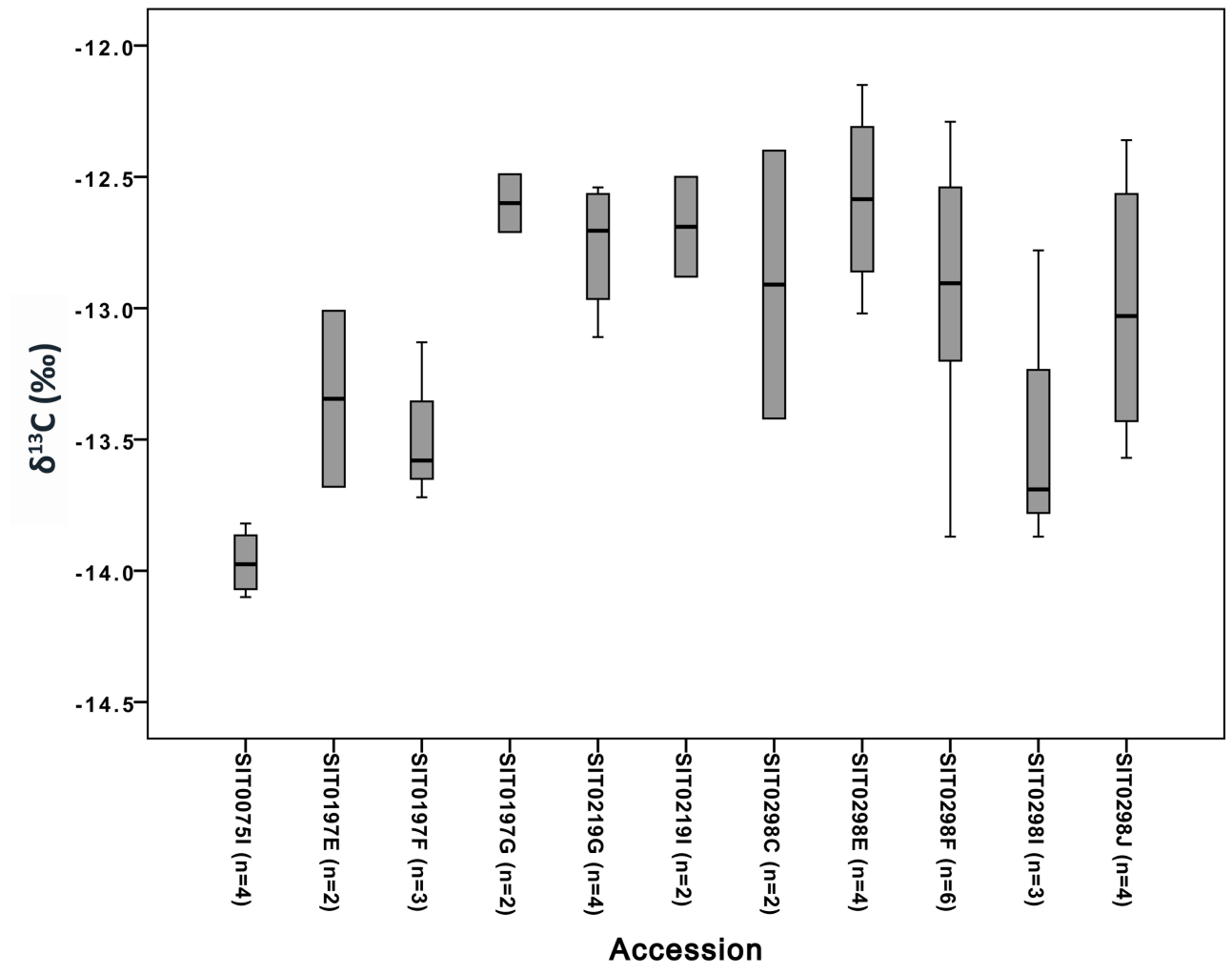

Figure 2c: Boxplot showing isotope values of different leaves and panicles from individual plants: (a) $\delta^{13} \mathrm{C}$ values from leaves; (b) $\delta^{13} \mathrm{C}$ values from panicles; and (c) $\delta^{15} \mathrm{~N}$ values from panicles.

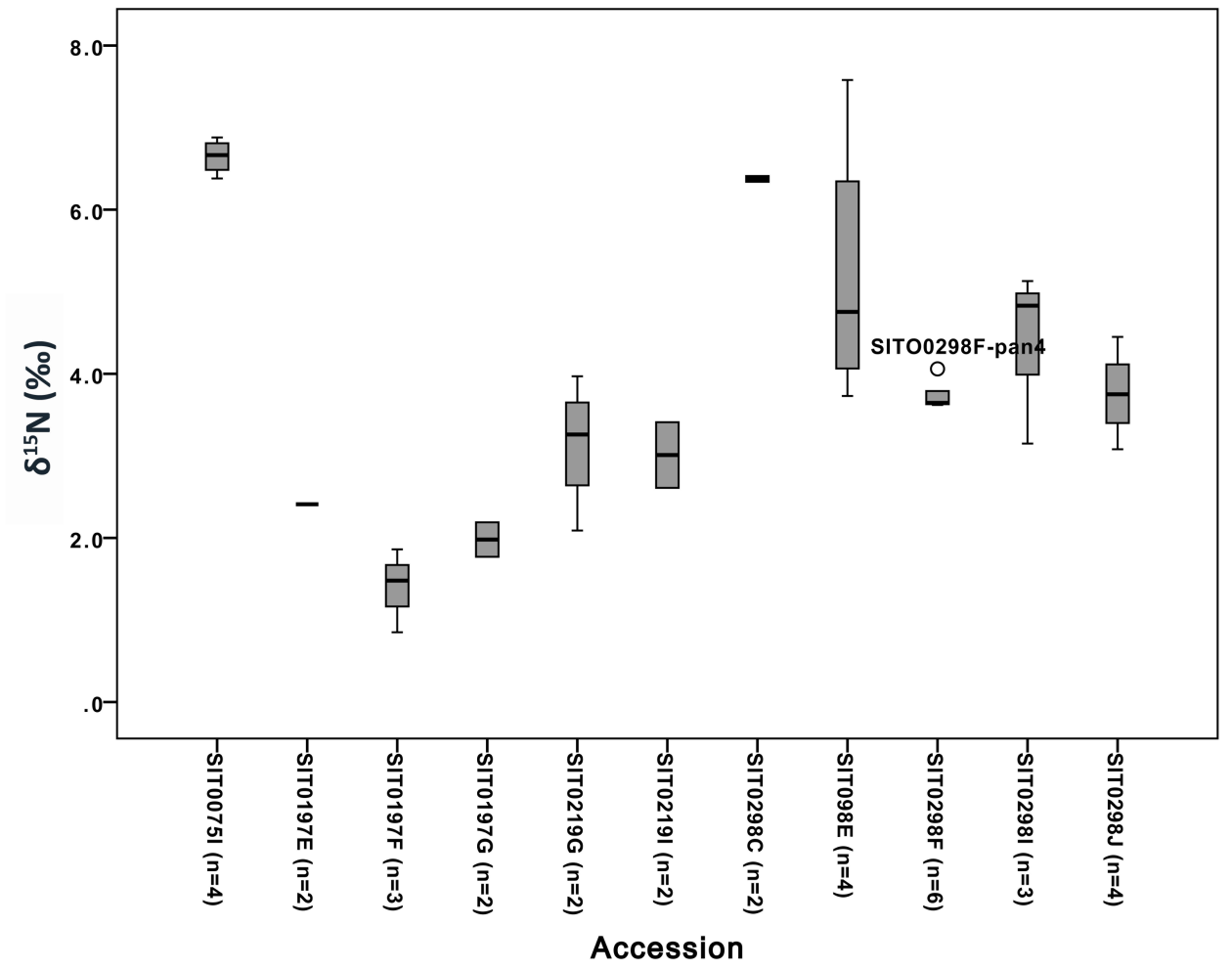


Figure 3a: Histogram of isotope values of 29 different accessions: (a) $\delta^{13} \mathrm{C}$ values from leaves; (b) $\delta^{13} \mathrm{C}$ values from grains; and (c) $\delta^{15} \mathrm{~N}$ values from grains

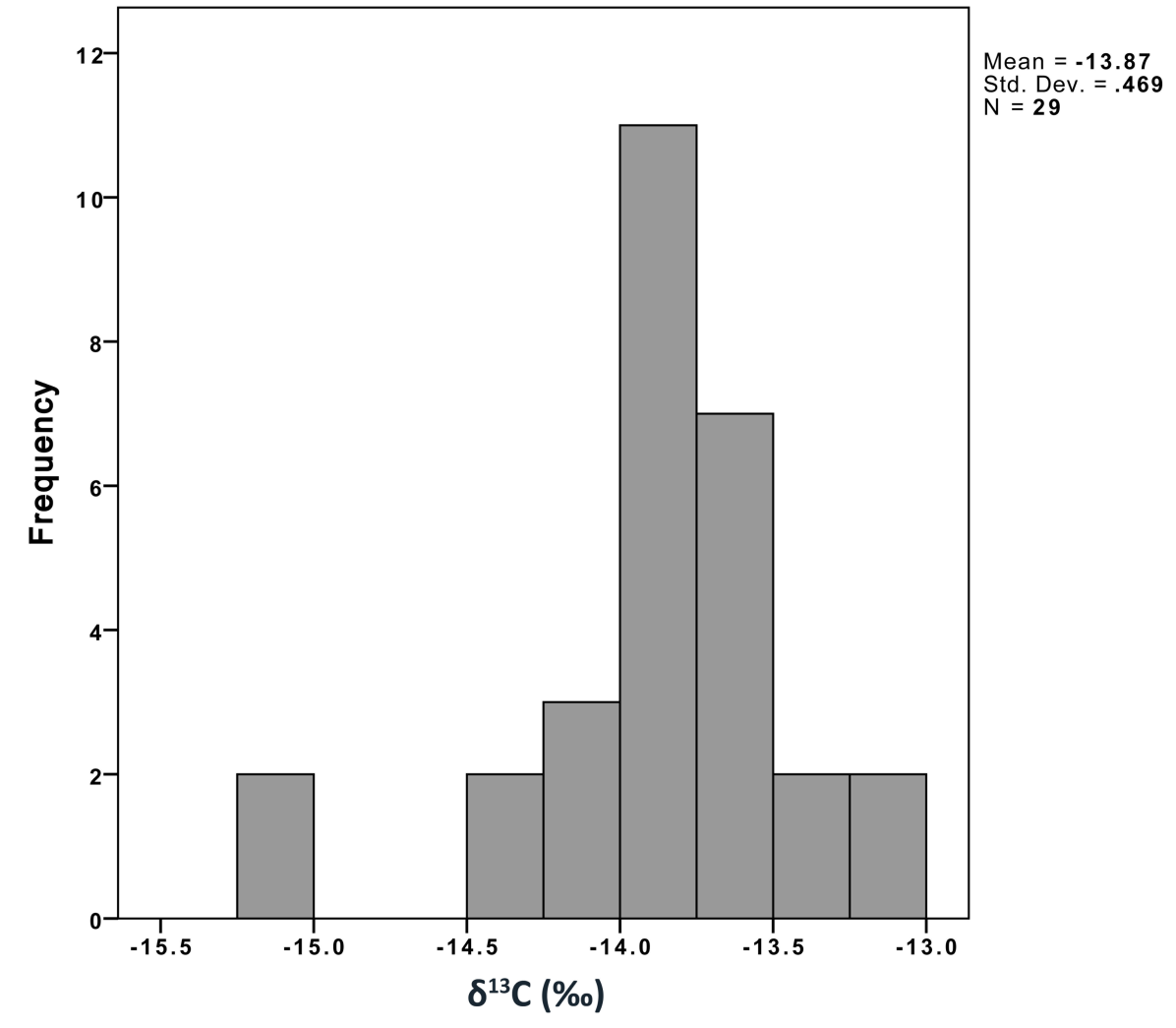

Figure 3b: Histogram of isotope values of 29 different accessions: (a) $\delta^{13} \mathrm{C}$ values from leaves; (b) $\delta^{13} \mathrm{C}$ values from grains; and (c) $\delta^{15} \mathrm{~N}$ values from grains

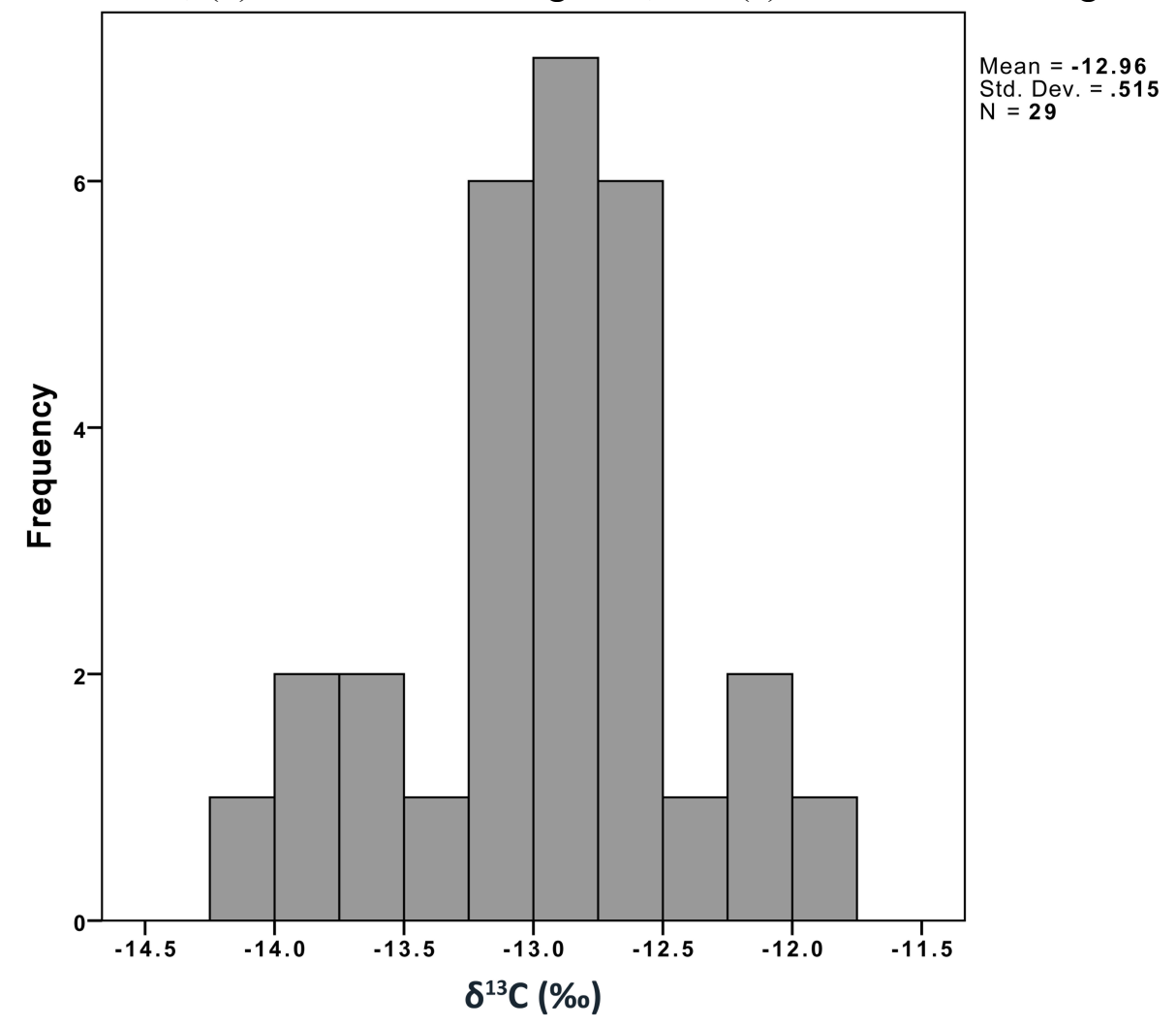


Figure 3c: Histogram of isotope values of 29 different accessions: (a) $\delta^{13} \mathrm{C}$ values from leaves; (b) $\delta^{13} \mathrm{C}$ values from grains; and (c) $\delta^{15} \mathrm{~N}$ values from grains

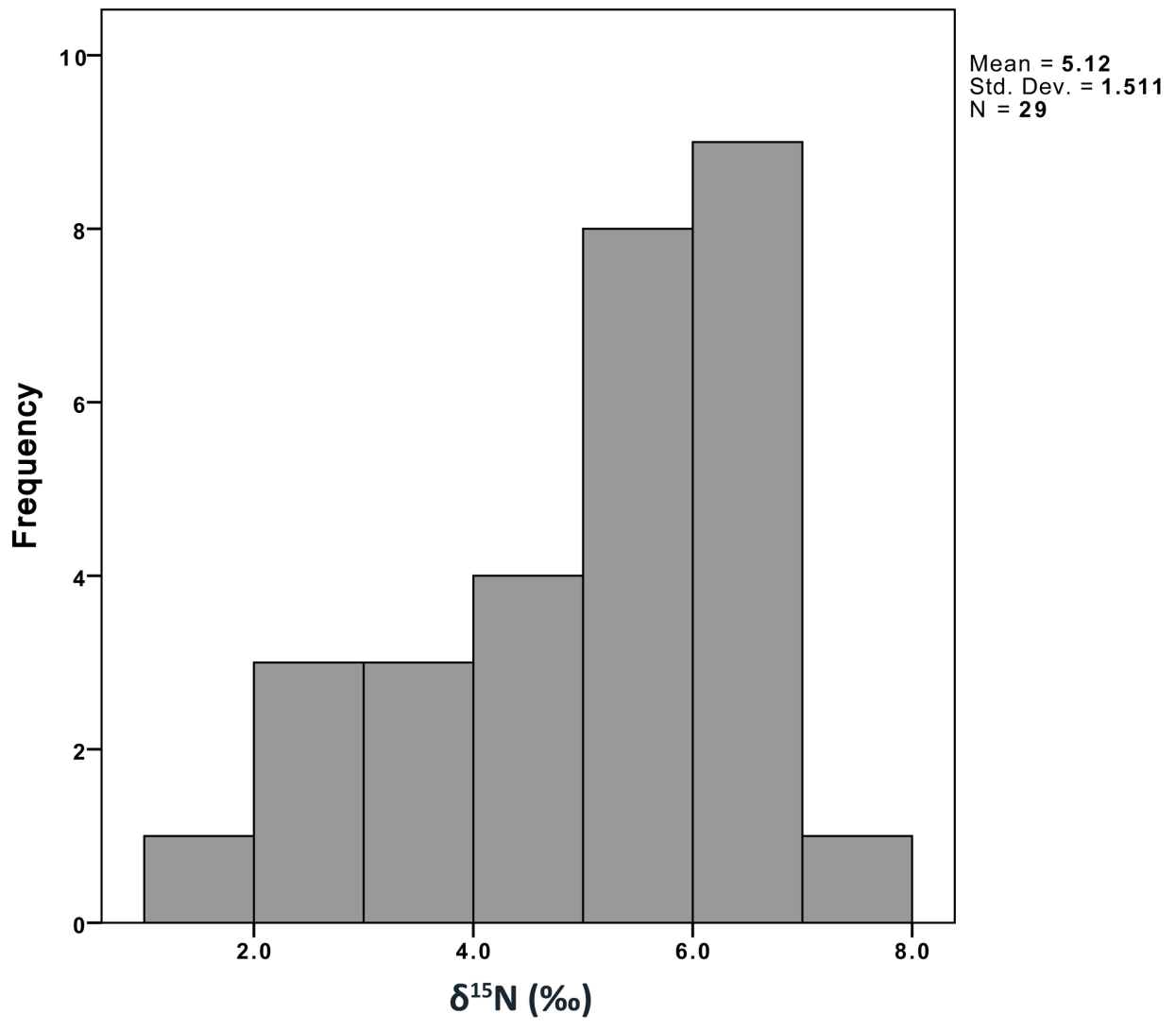

Figure 4: Scatter plot of grain isotope values

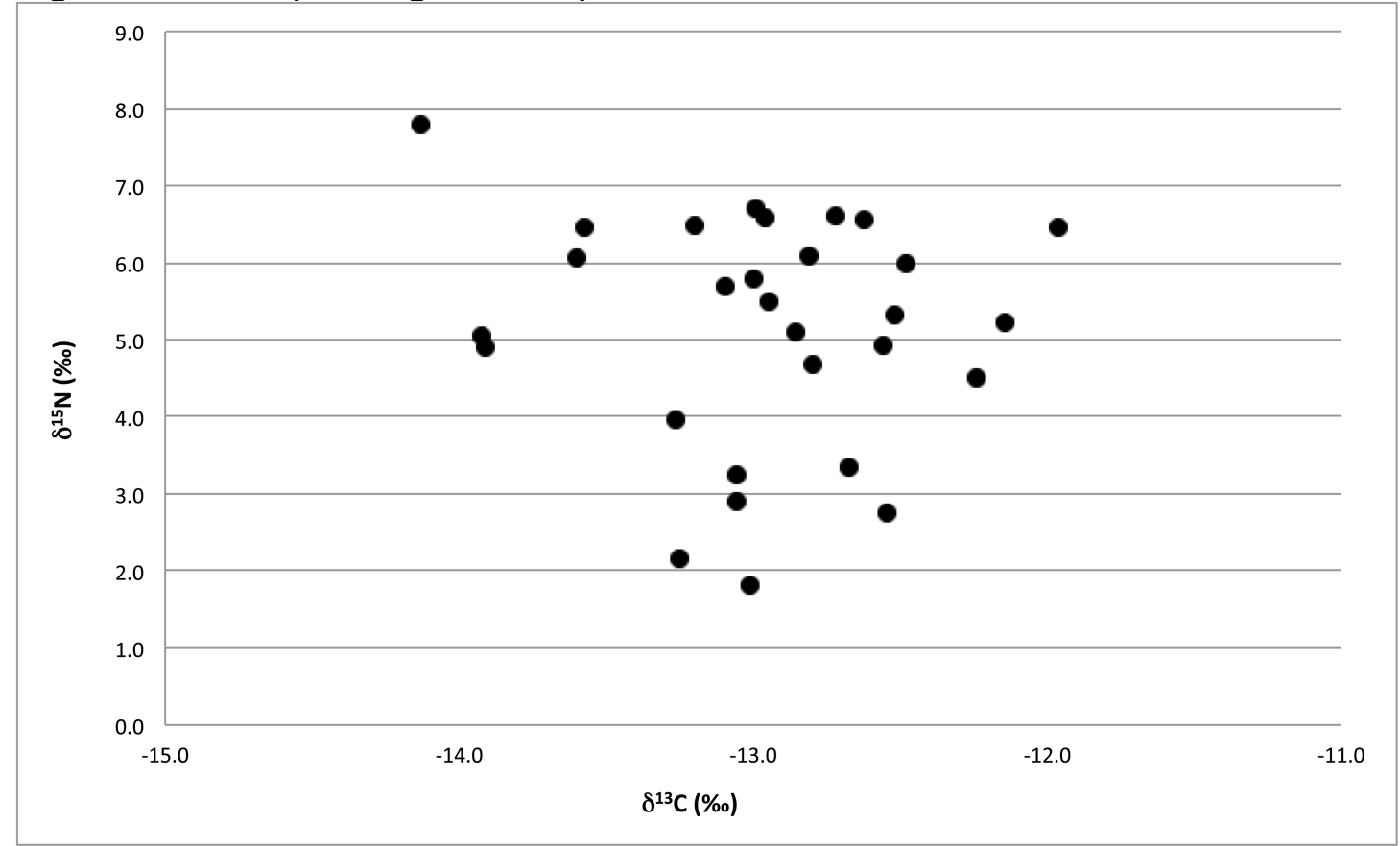


Figure 5: Histogram of differences between grain and leaf $\delta^{13} \mathrm{C}$ values from each accession

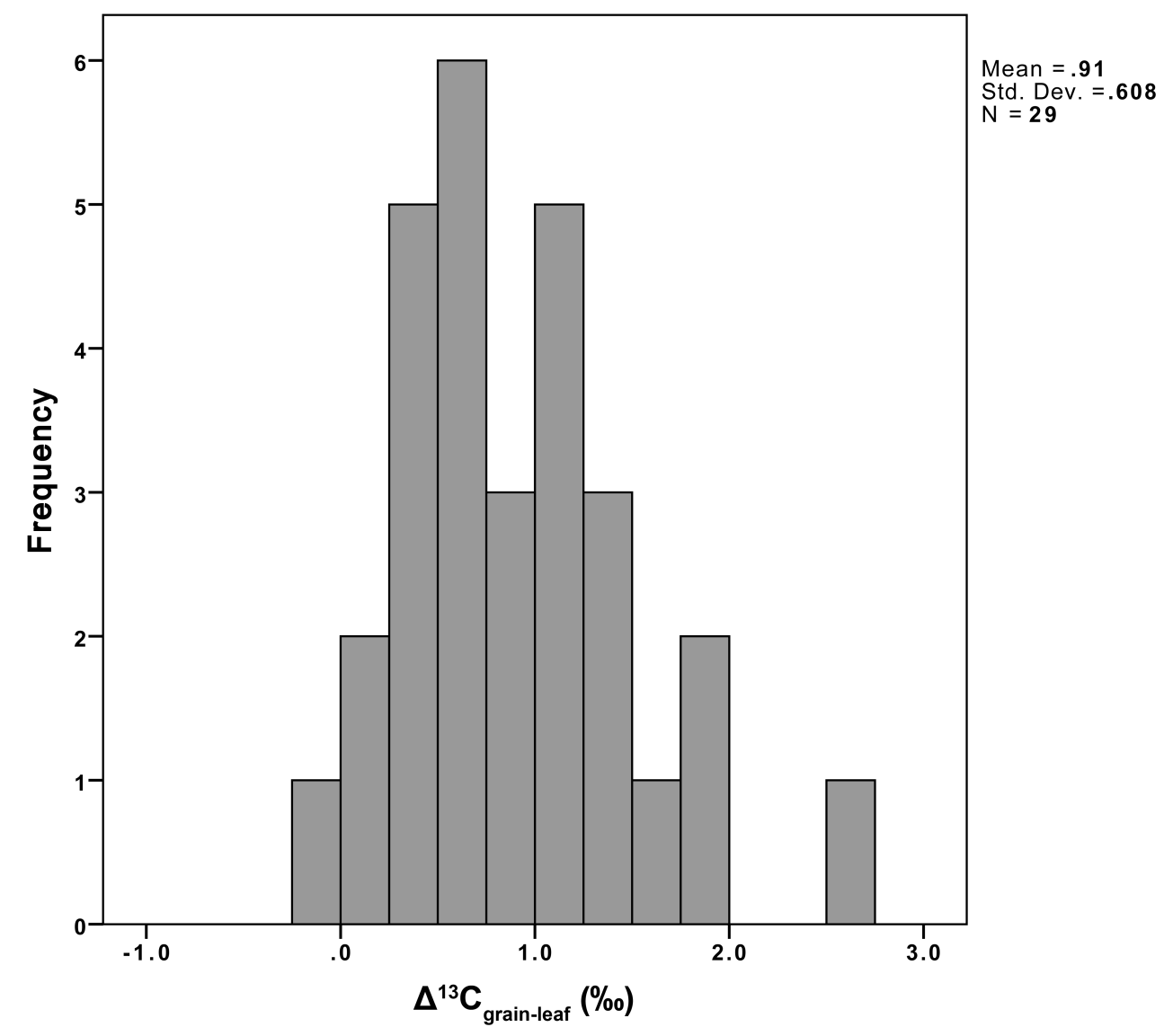




\section{TABLES}

Table 1: Summary of the experiments conducted. *This accession produced one panicle per plant

\begin{tabular}{|c|c|c|c|c|}
\hline & Short description & Leaf $\delta^{13} C$ & Grain $\delta^{13} \mathrm{C}$ & Grain $\delta^{15} \mathbf{N}$ \\
\hline Experiment 2 & Intra-plant comparison & $\begin{array}{l}\text { All available leaves from } 6 \\
\text { plants (total of } 74 \text { leaves) }\end{array}$ & $\begin{array}{l}20-30 \text { grains from each panicle } \\
\text { from } 11 \text { plants (total of } 36 \\
\text { panicles) }\end{array}$ & $\begin{array}{l}20-30 \text { grains from each panicle } \\
\text { from } 11 \text { plants (total of } 36 \\
\text { panicles) }\end{array}$ \\
\hline Experiment 3 & Intra-line comparison & $\begin{array}{l}\text { All leaves (homogenised into } \\
\text { one sample) from } 10 \\
\text { replicates of SIT0034 }\end{array}$ & $\begin{array}{l}20 \text { - } 30 \text { grains from } 10 \text { replicates } \\
\text { of SIT0034* }\end{array}$ & $\begin{array}{l}20 \text { - } 30 \text { grains from } 10 \text { replicates } \\
\text { of SIT0034* }\end{array}$ \\
\hline Experiment 4 & $\begin{array}{l}\text { Inter-accession } \\
\text { comparison }\end{array}$ & $\begin{array}{l}\text { All leaves (homogenised into } \\
\text { one sample) from } 29 \\
\text { accessions }\end{array}$ & $\begin{array}{l}20-30 \text { grains from all panicles } \\
\text { of } 29 \text { accessions }\end{array}$ & $\begin{array}{l}20-30 \text { grains from all panicles of } \\
29 \text { accessions }\end{array}$ \\
\hline
\end{tabular}


Table 2: Summary of within leaf and within panicle isotope data. ${ }^{*}$ Grains from SIT0264E contained too little nitrogen for reliable $\delta^{15} \mathrm{~N}$ values, and the data are therefore excluded from this study

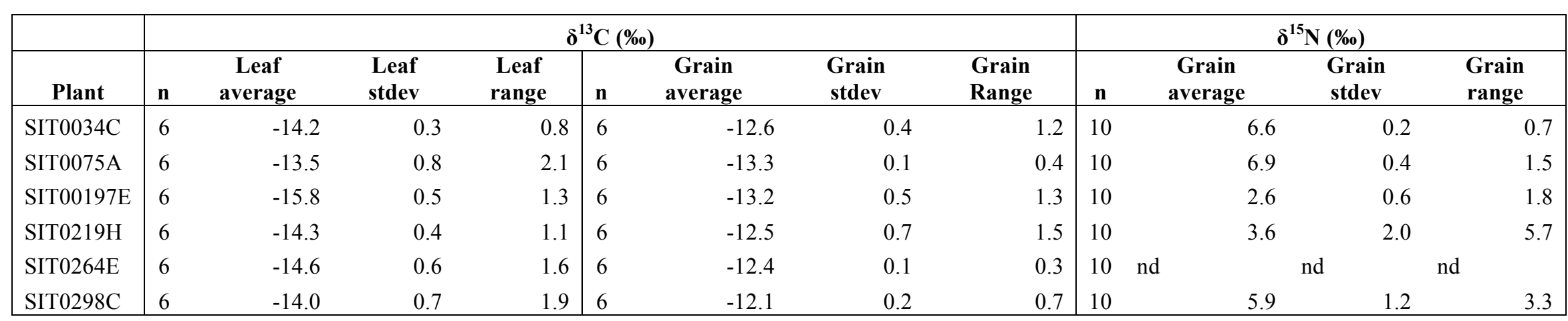


Table 3: Summary of carbon isotope data from different leaves of the same plant

\begin{tabular}{|lrrrr|}
\hline & \multicolumn{4}{c|}{$\boldsymbol{\delta}^{\mathbf{1 3}} \mathbf{C} \mathbf{( \% )}$} \\
\hline Plant & $\mathbf{n}$ & \multicolumn{1}{c|}{ Mean } & \multicolumn{1}{c|}{ St Dev } & \multicolumn{1}{c|}{ Range } \\
\hline SIT0034J & 11 & -13.4 & 0.2 & 0.6 \\
SIT0075I & 23 & -13.9 & 0.1 & 0.3 \\
SIT0219G & 8 & -14.0 & 0.6 & 1.8 \\
SIT0197E & 8 & -14.7 & 0.6 & 1.5 \\
SIT0264H & 8 & -14.4 & 0.4 & 1.1 \\
SIT0298F & 16 & -14.0 & 0.9 & 2.9 \\
\hline
\end{tabular}


Table 4: Summary of isotope data from different panicles of the same plant

\begin{tabular}{|lr|rrr|rrr|}
\hline & & \multicolumn{3}{c|}{$\boldsymbol{\delta}^{\mathbf{1 3}} \mathbf{C} \mathbf{( \% )}$} & \multicolumn{3}{c|}{$\boldsymbol{\delta}^{\mathbf{1 5}} \mathbf{N}(\mathbf{\%})$} \\
\hline \multicolumn{1}{|c|}{ Plant } & $\mathbf{n}$ & \multicolumn{1}{c|}{ Mean } & \multicolumn{1}{c|}{ St Dev } & \multicolumn{1}{c|}{ Range } & \multicolumn{1}{c|}{ Mean } & \multicolumn{1}{c|}{ St Dev } & Range \\
\hline SIT0075I & 4 & -14.0 & 0.1 & 0.3 & 6.6 & 0.2 & 0.5 \\
SIT0197E & 2 & -13.3 & 0.5 & 0.7 & 2.4 & 0.0 & 0.0 \\
SIT0197F & 3 & -13.5 & 0.3 & 0.6 & 1.4 & 0.5 & 1.0 \\
SIT0197G & 2 & -12.6 & 0.1 & 0.2 & 2.0 & 0.3 & 0.4 \\
SIT0219G & 4 & -12.8 & 0.3 & 0.6 & 3.1 & 0.8 & 1.9 \\
SIT0219I & 2 & -12.7 & 0.3 & 0.4 & 3.0 & 0.6 & 0.8 \\
SIT0298C & 2 & -12.9 & 0.7 & 1.0 & 6.4 & 0.0 & 0.1 \\
SIT0298E & 4 & -12.6 & 0.4 & 0.9 & 5.2 & 1.7 & 3.9 \\
SIT0298F & 6 & -13.0 & 0.6 & 1.6 & 3.7 & 0.2 & 0.4 \\
SIT0298I & 3 & -13.4 & 0.6 & 1.1 & 4.4 & 1.1 & 2.0 \\
SIT0298J & 4 & -13.0 & 0.5 & 1.2 & 3.8 & 0.6 & 1.4 \\
\hline
\end{tabular}


Table 5: Isotope data from 29 different accessions. Accessions marked with an asterix denote plants that were not mature at harvest

\begin{tabular}{|c|c|c|c|c|}
\hline Accession & $\begin{array}{c}\text { Leaf } \delta^{13} \mathrm{C} \\
(\%)\end{array}$ & $\begin{array}{c}\text { Grain } \delta^{13} \mathrm{C} \\
(\% 0)\end{array}$ & $\begin{array}{c}\text { Grain } \delta^{15} N \\
(\% 0)\end{array}$ & $\begin{array}{c}\text { Grain - Leaf } \delta^{13} \mathrm{C} \\
(\%)\end{array}$ \\
\hline SIT0038 & -13.6 & -12.6 & 6.6 & 0.9 \\
\hline SIT0132 & -13.1 & -12.0 & 6.5 & 1.2 \\
\hline SIT0134 & -13.4 & -12.5 & 5.3 & 0.9 \\
\hline SIT0139 & -13.1 & -12.7 & 6.6 & 0.4 \\
\hline SIT0199 & -13.8 & -12.7 & 3.4 & 1.1 \\
\hline SIT0222* & -14.0 & -12.6 & 4.9 & 1.4 \\
\hline SIT0233 & -14.0 & -12.9 & 5.1 & 1.2 \\
\hline SIT0238 & -13.6 & -12.9 & 5.5 & 0.6 \\
\hline SIT0241* & -14.5 & -13.1 & 3.2 & 1.4 \\
\hline SIT0256 & -14.3 & -13.9 & 4.9 & 0.4 \\
\hline SIT0287 & -14.0 & -13.6 & 6.1 & 0.4 \\
\hline SIT0300 & -13.3 & -13.1 & 5.7 & 0.2 \\
\hline SIT0338 & -13.9 & -12.2 & 4.5 & 1.7 \\
\hline SIT0424* & -15.1 & -12.5 & 2.7 & 2.5 \\
\hline SIT0426 & -13.5 & -13.2 & 6.5 & 0.3 \\
\hline SIT0462 & -13.8 & -12.8 & 4.7 & 1.0 \\
\hline SIT0492 & -13.7 & -13.1 & 2.9 & 0.6 \\
\hline SIT0503* & -15.2 & -13.3 & 4.0 & 1.9 \\
\hline SIT0510 & -13.8 & -12.8 & 6.1 & 1.0 \\
\hline SIT0533 & -13.9 & -13.3 & 2.2 & 0.7 \\
\hline SIT0541 & -13.8 & -13.9 & 5.0 & -0.1 \\
\hline SIT0559 & -13.5 & -13.0 & 6.7 & 0.5 \\
\hline SIT0565 & -13.9 & -13.6 & 6.4 & 0.3 \\
\hline SIT0586 & -14.1 & -12.1 & 5.2 & 1.9 \\
\hline SIT0589* & -13.7 & -13.0 & 1.8 & 0.6 \\
\hline SIT0592 & -14.2 & -14.1 & 7.8 & 0.1 \\
\hline SIT0595 & -13.7 & -13.0 & 6.6 & 0.7 \\
\hline SIT0598 & -13.8 & -13.0 & 5.8 & 0.8 \\
\hline SIT0620 & -13.9 & -12.5 & 6.0 & 1.4 \\
\hline
\end{tabular}




\section{SUPPLEMENTARY FIGURES}

Figure S1: Scatter graph showing the grain $\delta^{15} \mathrm{~N}$ values plotted by days from planting to maturity. Note that the samples plotted at 130 days were not mature at harvest (which took place at 123 days)

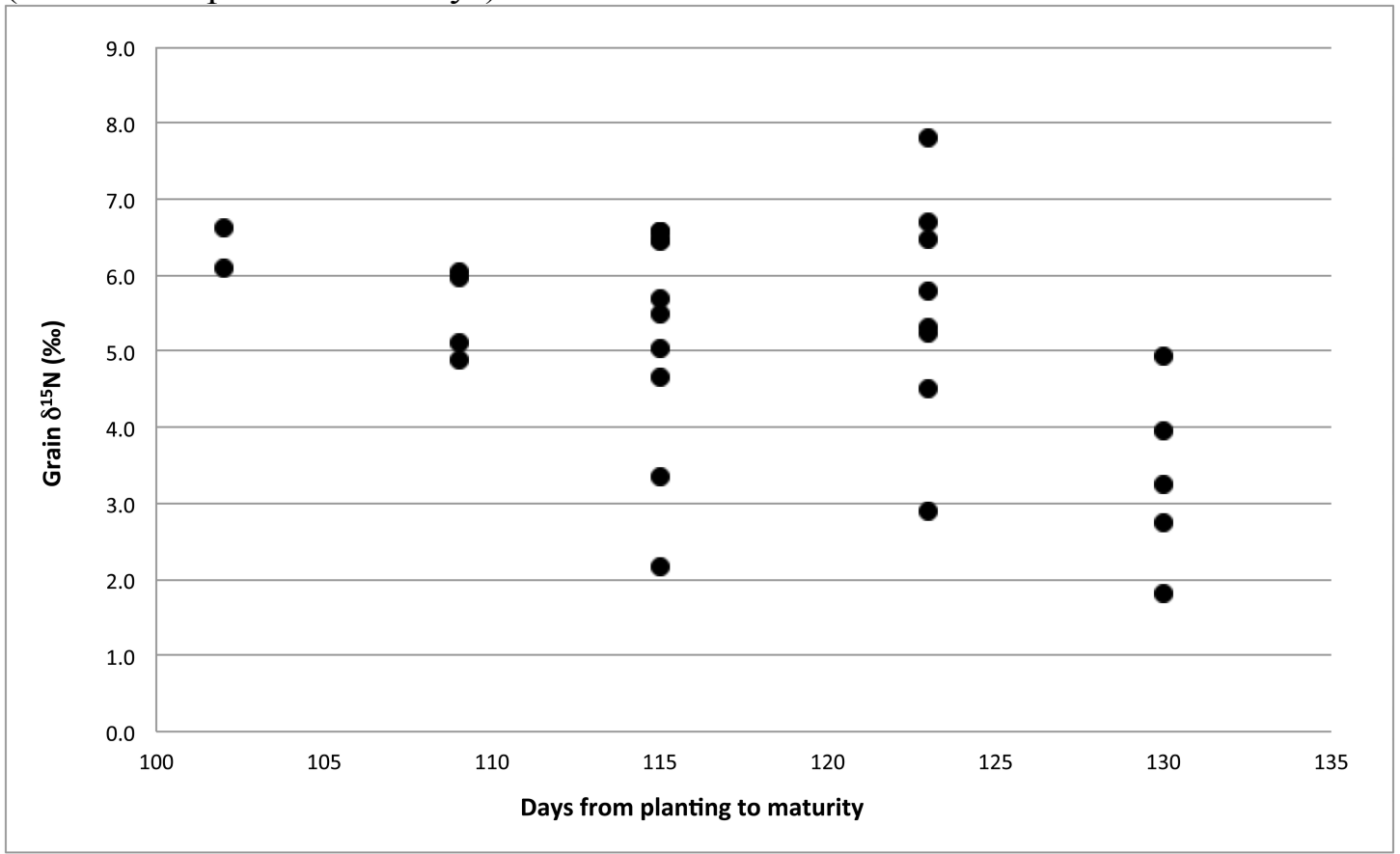

Figure S2: Scatter graph showing leaf $\delta^{13} \mathrm{C}$ value plotted by number of tillers

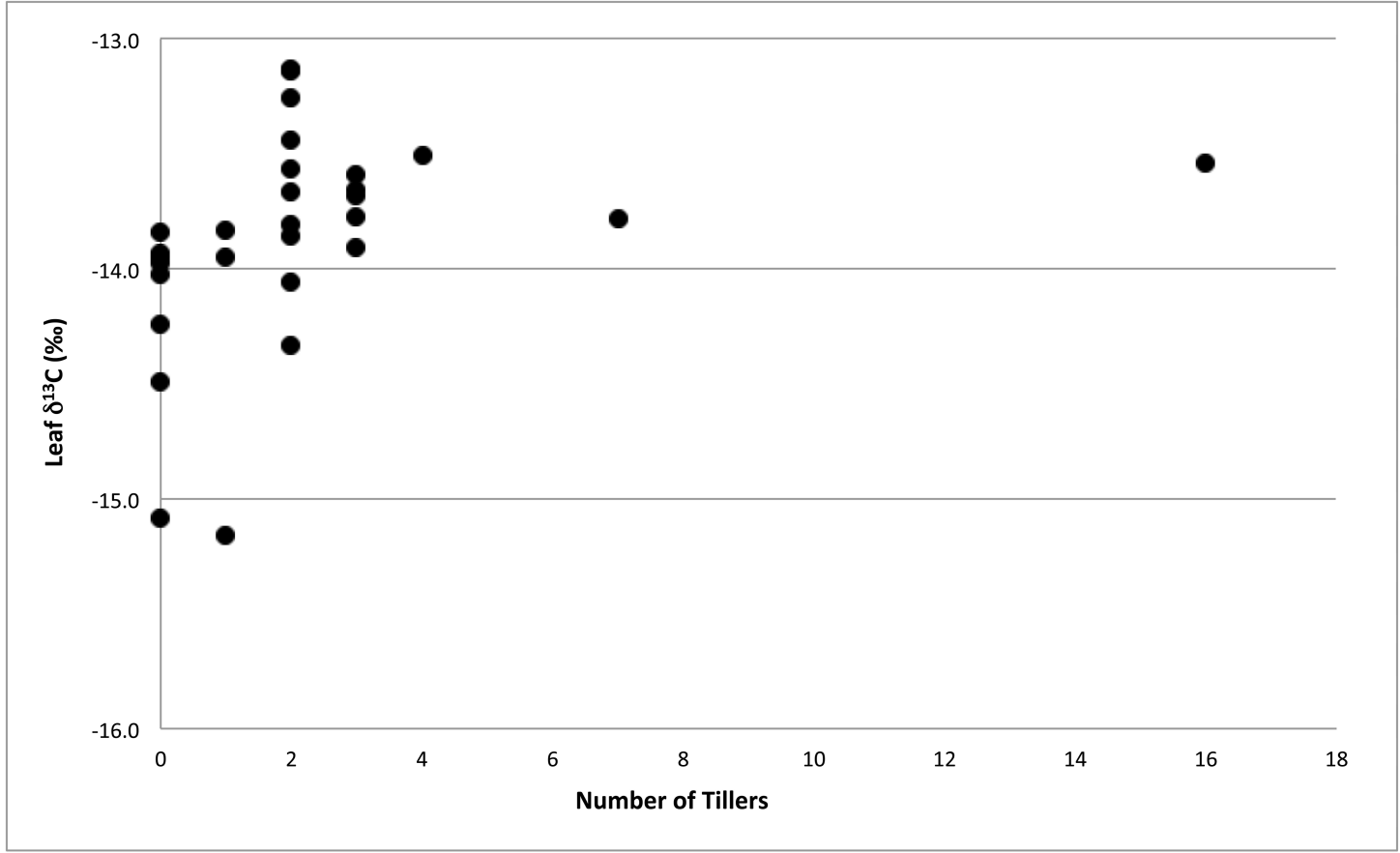


Figure S3: Scatter graph showing leaf $\delta^{13} \mathrm{C}$ value plotted by number of leaves

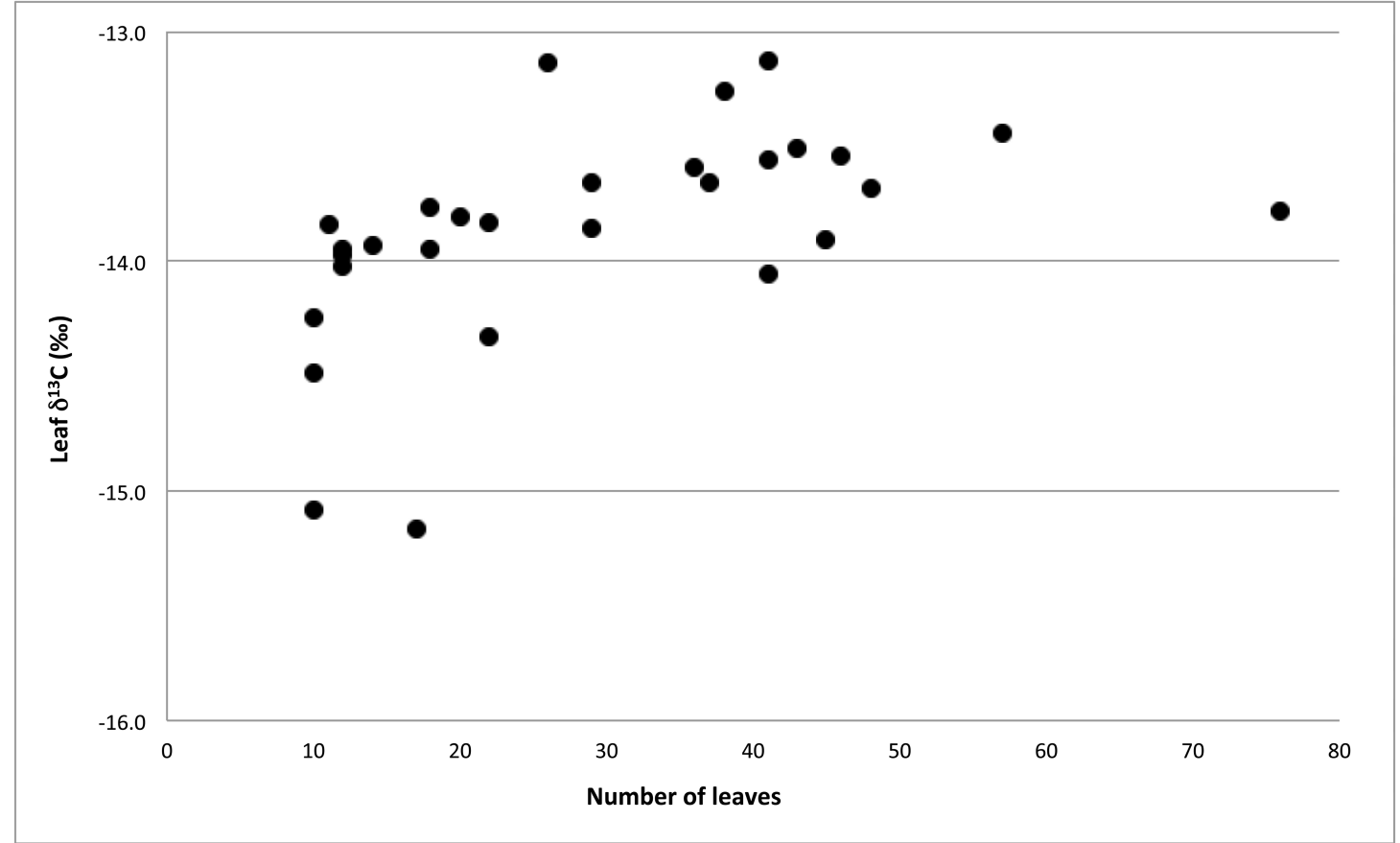

Figure S4: Scatter graph showing leaf $\delta^{13} \mathrm{C}$ value plotted by flowering time

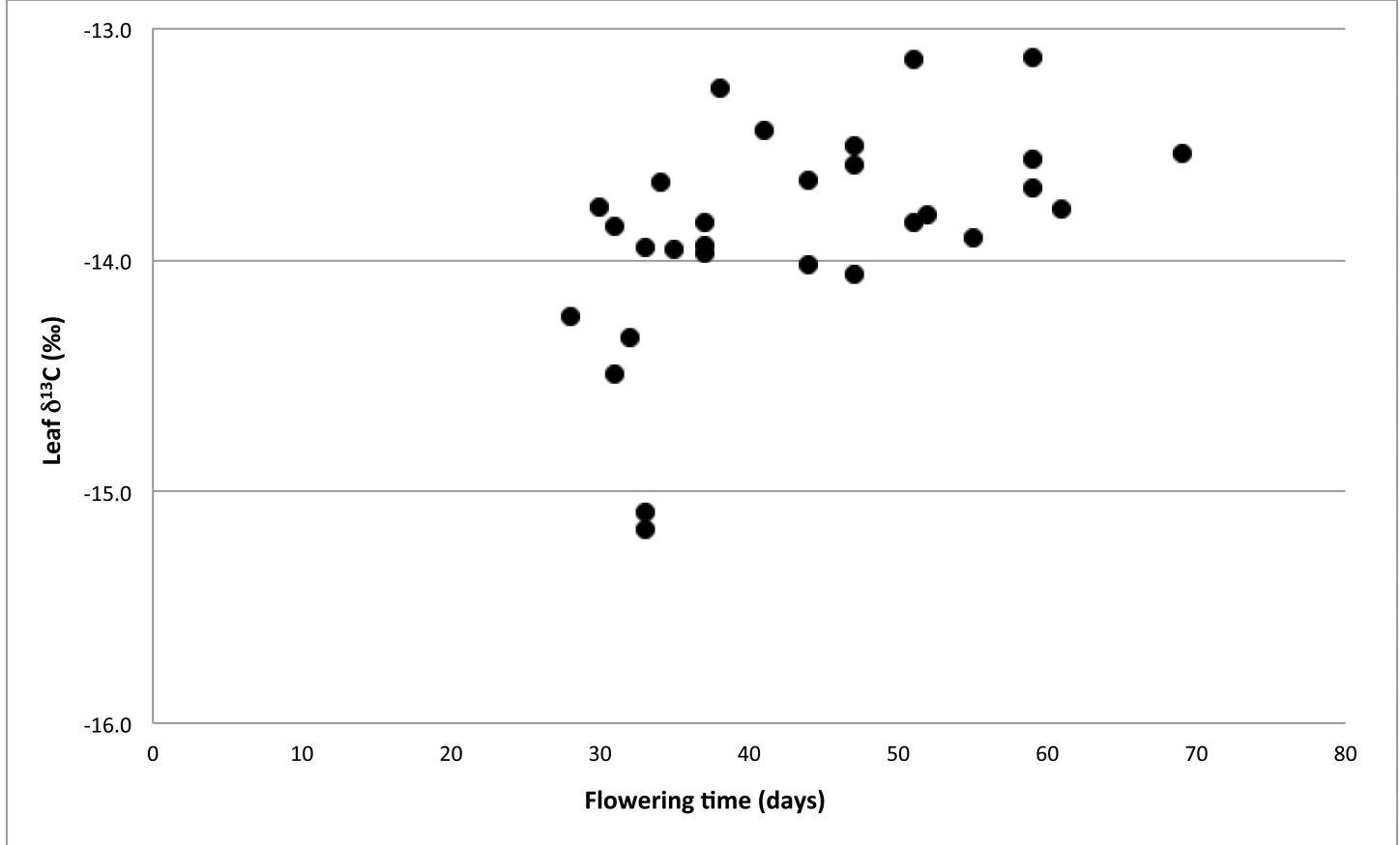


Figure S5: Scatter graph showing grain $\delta^{15} \mathrm{~N}$ value plotted by latitude of original germplasm collection

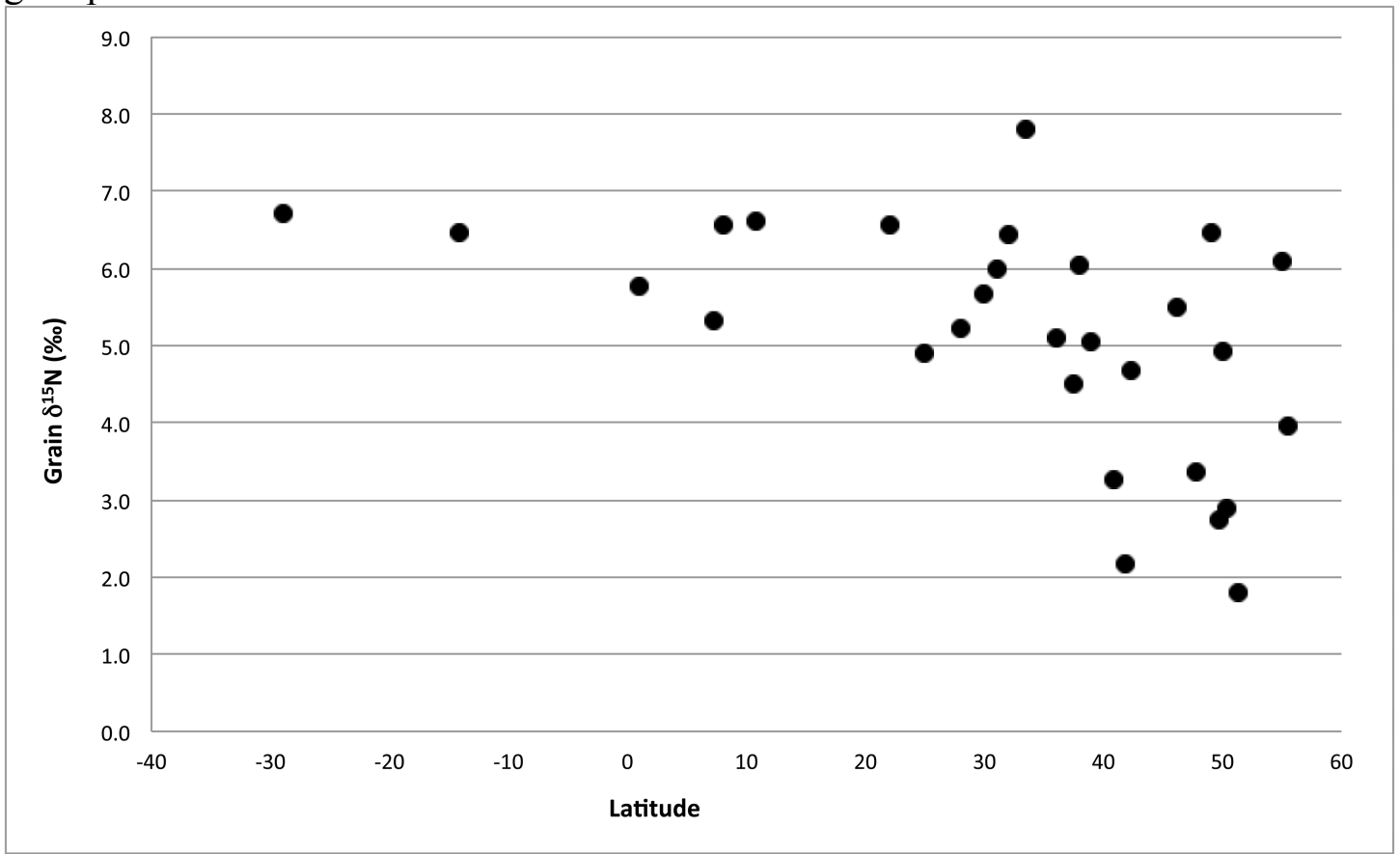

Figure S6: Scatter graph showing grain $\delta^{15} \mathrm{~N}$ value plotted by flowering time

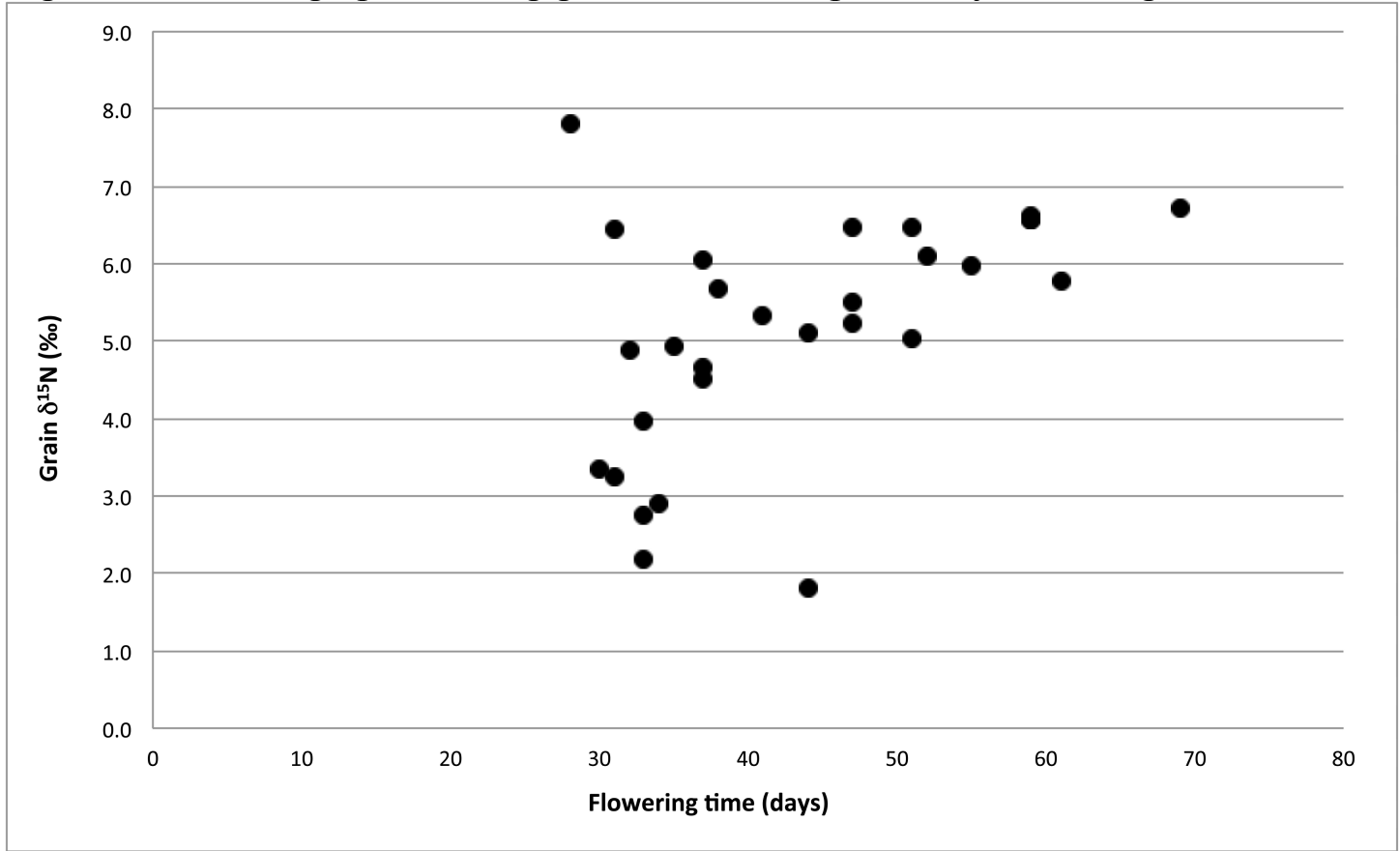




\section{SUPPLEMENTARY TABLES}

Table S1: Ancilliary information about accessions used in this study. Accessions marked with an asterix denotes plants harvested before maturity. Seed was obtained from the following germplasm banks: the National Institute of Agrobiological Sciences, Japan (NIAS, 2-1-2 Kannondai, Tsukuba, Ibaraki 305-8602, Japan); Leibniz-Institut für Pflanzengenetik und Kulturpflanzenforschung, Gatersleben, Germany (IPK, Corrensstraße 3, 06466 Gatersleben, Germany); the N.I. Vavilov Institute of Plant Genetic Resources, Russia (VIR, 13-ya liniya, 64/39, St Petersburg, Russia, 199178); The International Crops Research Institute for the Semi-Arid Tropics, India (ICRISAT, Building Number 305, Dryland Cereals, Patancheru, Hyderabad, Telangana 502324, India); and the United States Department of Agriculture Agricultural Research Centre (USDA-ARS, NCRPIS, 1305 State Avenue, Ames, Iowa 50014-7913)

\begin{tabular}{|c|c|c|c|c|c|c|c|c|c|c|c|c|c|}
\hline Accession & Germplasm Bank & Country & Habit & $\begin{array}{l}\text { Intensity } \\
\text { of green }\end{array}$ & $\begin{array}{l}\text { Number } \\
\text { of tillers }\end{array}$ & $\begin{array}{l}\text { Plant } \\
\text { height }\end{array}$ & $\begin{array}{c}\text { Number } \\
\text { of } \\
\text { panicles }\end{array}$ & $\begin{array}{l}\text { Number } \\
\text { of leaves }\end{array}$ & Longitude & Latitude & $\begin{array}{c}\text { Flowering } \\
\text { time }\end{array}$ & $\begin{array}{c}\text { Photoperiod } \\
\text { response }\end{array}$ & $\begin{array}{c}\text { Days } \\
\text { until } \\
\text { harvest }\end{array}$ \\
\hline SIT0038 & ICRISAT & India & 1 & 2 & 2 & 69.5 & 4 & 41 & 71.38 & 22.07 & 59 & 73 & 115 \\
\hline SIT0132 & ICRISAT & Malawi & 1 & 1 & 2 & 84.5 & 3 & 26 & 33.65 & -14.16 & 51 & 66 & 123 \\
\hline SIT0134 & ICRISAT & Cameroon & 2 & 2 & 2 & 33.5 & nd & 57 & 13.58 & 7.32 & 41 & 59 & 123 \\
\hline SIT0139 & ICRISAT & India & 1 & 3 & 2 & 64.5 & 6 & 41 & 76.65 & 10.78 & 59 & nd & 102 \\
\hline SIT0199 & IPK Gatersleben & Slovakia & 1 & 2 & 3 & 19.2 & 22 & 18 & 18.13 & 47.77 & 30 & 27 & 115 \\
\hline SIT0222 & IPK Gatersleben & Czech Republic & 1 & 2 & 1 & 30 & nd & 18 & 15.87 & 49.98 & 35 & 26 & nd \\
\hline SIT0233 & IPK Gatersleben & South Korea & 0 & 2 & 0 & 70 & 1 & 12 & 127.00 & 36.00 & 44 & 86 & 109 \\
\hline SIT0238 & IPK Gatersleben & Italy & 1 & 2 & 3 & 69.5 & 5 & 36 & 13.10 & 46.26 & 47 & 69 & 115 \\
\hline SIT0241 & IPK Gatersleben & North Korea & 0 & 2 & 0 & 30.5 & nd & 10 & 126.66 & 40.83 & 31 & 105 & nd \\
\hline SIT0256 & $\begin{array}{l}\text { National Institute of Agrobotanical } \\
\text { Science }\end{array}$ & China & 1 & 2 & 2 & 35.6 & 14 & 22 & 101.00 & 25.00 & 32 & 136 & 109 \\
\hline SIT0287 & $\begin{array}{l}\text { National Institute of Agrobotanical } \\
\text { Science }\end{array}$ & Japan & 0 & 3 & 0 & 39.4 & 4 & 12 & 139.00 & 37.90 & 37 & 44 & 109 \\
\hline SIT0300 & $\begin{array}{l}\text { National Institute of Agrobotanical } \\
\text { Science }\end{array}$ & Pakistan & 1 & 1 & 2 & 38 & 11 & 38 & 70.00 & 30.00 & 38 & 29 & 115 \\
\hline SITn228 & Vavilan & China & 0 & 3 & 0 & 56.5 & 2 & 14 & $117 \mathrm{n}$ & 3750 & 37 & 52 & 172 \\
\hline
\end{tabular}




\begin{tabular}{|c|c|c|c|c|c|c|c|c|c|c|c|c|c|}
\hline SIT0462 & Vavilov & Georgia & 0 & 2 & 0 & 36.9 & 3 & 11 & 42.99 & 42.33 & 37 & 55 & 115 \\
\hline SIT0492 & Vavilov & $\begin{array}{l}\text { Russian } \\
\text { Federation }\end{array}$ & 1 & 2 & 2 & 20 & 23 & 29 & 143.01 & 50.42 & 34 & 27 & 123 \\
\hline SIT0503 & Vavilov & $\begin{array}{l}\text { Russian } \\
\text { Federation }\end{array}$ & 1 & 3 & 1 & 40 & 2 & 17 & 37.37 & 55.45 & 33 & 33 & nd \\
\hline SIT0510 & Vavilov & $\begin{array}{l}\text { Russian } \\
\text { Federation }\end{array}$ & 1 & 3 & 2 & 16 & 1 & 20 & 82.56 & 55.01 & 52 & 90 & 102 \\
\hline SIT0533 & Vavilov & Uzbekistan & 0 & 2 & 0 & 36.5 & 3 & 12 & 62.97 & 41.77 & 33 & 53 & 115 \\
\hline SIT0541 & USDA ARS GRN & Turkey & 1 & 2 & 1 & 65.2 & 10 & 22 & 35.00 & 39.00 & 51 & 25 & 115 \\
\hline SIT0559 & USDA ARS GRN & South Africa & 1 & 2 & 16 & 43.2 & 5 & 46 & 24.00 & -29.00 & 69 & 92 & 123 \\
\hline SIT0565 & USDA ARS GRN & Iran & 1 & 1 & 2 & 28.7 & 13 & 29 & 53.00 & 32.00 & 31 & 20 & 115 \\
\hline SIT0586 & USDA ARS GRN & Nepal & 1 & 2 & 2 & 53 & 7 & 41 & 84.00 & 28.00 & 47 & 75 & 123 \\
\hline SIT0589 & USDA ARS GRN & Belgium & 1 & 2 & 3 & 62.3 & nd & 37 & 4.72 & 51.25 & 44 & 14 & nd \\
\hline SIT0592 & USDA ARS GRN & Lebanon & 0 & 3 & 0 & 18.5 & 20 & 10 & 35.50 & 33.50 & 28 & 37 & 123 \\
\hline SIT0595 & USDA ARS GRN & Ethiopia & 1 & 2 & 3 & 94.7 & 6 & 48 & 38.00 & 8.00 & 59 & 95 & 115 \\
\hline SIT0598 & USDA ARS GRN & Kenya & 1 & 2 & 7 & 67 & 4 & 76 & 38.00 & 1.00 & 61 & 88 & 123 \\
\hline SIT0620 & USDA ARS GRN & Morocco & 1 & 2 & 3 & 51.7 & 4 & 45 & -7.13 & 31.05 & 55 & 17 & 109 \\
\hline
\end{tabular}


Table S2: Table showing $\delta^{13} \mathrm{C}$ values for different points along 6 leaves and $\delta^{13} \mathrm{C}$ and $\delta^{15} \mathrm{~N}$ values for grains from 6 panicles . ${ }^{*}$ Samples were taken at approximately equal intervals along the leaf or panicle.

\begin{tabular}{|c|c|c|c|c|}
\hline Accession & $\begin{array}{c}\text { Relative } \\
\text { position* }\end{array}$ & $\begin{array}{c}\text { Leaf } \delta^{13} \mathrm{C} \\
(\%)\end{array}$ & $\begin{array}{c}\text { Grain } \delta^{13} \mathrm{C} \\
(\% 0)\end{array}$ & $\begin{array}{c}\text { Grain } \delta^{15} \mathrm{~N} \\
(\%)\end{array}$ \\
\hline \multirow{10}{*}{ SITO0034C } & 1 & -14.3 & -12.7 & 7.1 \\
\hline & 2 & -14.6 & -13.2 & 6.7 \\
\hline & 3 & -14.2 & -12.4 & 7.0 \\
\hline & 4 & -14.3 & -12.4 & 6.6 \\
\hline & 5 & -13.8 & -12.0 & 6.7 \\
\hline & 6 & -13.9 & -12.7 & 6.5 \\
\hline & 7 & nd & nd & 6.4 \\
\hline & 8 & nd & nd & 6.5 \\
\hline & 9 & nd & nd & 6.7 \\
\hline & 10 & nd & nd & 6.3 \\
\hline \multirow{10}{*}{ SITO0075A } & 1 & -15.0 & -13.3 & 6.8 \\
\hline & 2 & -13.8 & -13.3 & 6.9 \\
\hline & 3 & -12.9 & -13.1 & 7.0 \\
\hline & 4 & -12.9 & -13.5 & 6.0 \\
\hline & 5 & -13.3 & -13.2 & 7.3 \\
\hline & 6 & -13.2 & -13.3 & 6.5 \\
\hline & 7 & nd & nd & 6.7 \\
\hline & 8 & nd & nd & 7.1 \\
\hline & 9 & nd & nd & 7.2 \\
\hline & 10 & nd & nd & 7.5 \\
\hline \multirow{10}{*}{ SITO0197E } & 1 & -16.4 & -12.6 & 2.9 \\
\hline & 2 & -16.2 & -13.5 & 1.9 \\
\hline & 3 & -15.6 & -12.9 & 1.6 \\
\hline & 4 & -15.6 & -13.1 & 3.4 \\
\hline & 5 & -15.6 & -13.9 & 2.3 \\
\hline & 6 & -15.1 & -13.5 & 2.8 \\
\hline & 7 & nd & nd & 2.3 \\
\hline & 8 & nd & nd & 3.3 \\
\hline & 9 & nd & nd & 3.0 \\
\hline & 10 & nd & nd & 2.4 \\
\hline \multirow{9}{*}{ SITO0219H } & 1 & -14.5 & -13.3 & 5.5 \\
\hline & 2 & -13.7 & -13.4 & 1.4 \\
\hline & 3 & -14.5 & -12.1 & 4.5 \\
\hline & 4 & -13.9 & -12.3 & 1.7 \\
\hline & 5 & -14.4 & -12.0 & 7.1 \\
\hline & 6 & -14.8 & -11.9 & 1.6 \\
\hline & 7 & nd & nd & 3.9 \\
\hline & 8 & nd & nd & 1.4 \\
\hline & 9 & nd & nd & 4.2 \\
\hline
\end{tabular}




\begin{tabular}{|c|cccc|} 
& 10 & nd & nd & 4.5 \\
\cline { 2 - 4 } SITO0264E & 1 & -13.6 & -12.5 & nd \\
& 2 & -14.3 & -12.6 & nd \\
& 3 & -15.1 & -12.3 & nd \\
& 4 & -15.0 & -12.4 & nd \\
& 5 & -15.2 & -12.3 & nd \\
& 6 & -14.7 & -12.3 & nd \\
\hline & 1 & -15.2 & -12.6 & 5.7 \\
& 2 & -14.2 & -12.1 & 6.2 \\
& 3 & -13.3 & -11.9 & 8.2 \\
& 4 & -13.4 & -12.2 & 4.9 \\
& 5 & -13.7 & -12.0 & 4.9 \\
& 6 & -14.4 & -12.1 & 7.8 \\
& 7 & nd & nd & 5.1 \\
& 8 & nd & nd & 5.9 \\
& 9 & nd & nd & 4.9 \\
& 10 & nd & nd & 5.0 \\
\hline
\end{tabular}


Table S3: Table showing $\delta^{13} \mathrm{C}$ values of each homogenized leaf from 6 plants. Leaves were numbered from the bottom of a stem to the top, where multiple stems were present, leaf numbering is continuous between stems.

\begin{tabular}{|c|c|c|}
\hline Plant & $\begin{array}{c}\text { Leaf } \\
\text { number* }\end{array}$ & $\delta^{13} \mathrm{C}(\%)$ \\
\hline \multirow{11}{*}{ SIT0034J } & 1 & -13.7 \\
\hline & 2 & -13.5 \\
\hline & 3 & -13.2 \\
\hline & 4 & -13.4 \\
\hline & 5 & -13.3 \\
\hline & 6 & -13.1 \\
\hline & 7 & -13.4 \\
\hline & 8 & -13.4 \\
\hline & 9 & -13.5 \\
\hline & 10 & -13.4 \\
\hline & 11 & -13.5 \\
\hline \multirow{23}{*}{ SIT0075I } & 1 & -14.0 \\
\hline & 2 & -13.8 \\
\hline & 3 & -13.9 \\
\hline & 4 & -13.8 \\
\hline & 5 & -14.0 \\
\hline & 6 & -13.9 \\
\hline & 7 & -13.8 \\
\hline & 8 & -14.0 \\
\hline & 9 & -14.0 \\
\hline & 10 & -14.0 \\
\hline & 11 & -13.8 \\
\hline & 12 & -13.9 \\
\hline & 13 & -13.8 \\
\hline & 14 & -13.9 \\
\hline & 15 & -13.8 \\
\hline & 16 & -13.8 \\
\hline & 17 & -14.1 \\
\hline & 18 & -13.9 \\
\hline & 19 & -14.0 \\
\hline & 20 & -14.1 \\
\hline & 21 & -13.7 \\
\hline & 22 & -14.0 \\
\hline & 23 & -14.1 \\
\hline \multirow{8}{*}{ SIT0197E } & 1 & -13.9 \\
\hline & 2 & -13.7 \\
\hline & 3 & -14.1 \\
\hline & 4 & -15.3 \\
\hline & 5 & -15.2 \\
\hline & 6 & -15.2 \\
\hline & 7 & -15.2 \\
\hline & 8 & -14.9 \\
\hline \multirow{7}{*}{ SIT0219G } & 1 & -14.2 \\
\hline & 2 & -13.6 \\
\hline & 3 & -14.3 \\
\hline & 4 & -13.7 \\
\hline & 5 & -14.9 \\
\hline & 6 & -14.5 \\
\hline & 7 & -13.1 \\
\hline
\end{tabular}




\begin{tabular}{|c|cc|}
\hline & 8 & -13.7 \\
\hline \multirow{5}{*}{ SIT0264H } & 1 & -14.9 \\
& 2 & -15.0 \\
& 3 & -14.8 \\
& 4 & -14.4 \\
& 5 & -14.1 \\
& 6 & -14.1 \\
& 7 & -14.0 \\
& 8 & -13.9 \\
\hline \multirow{5}{*}{ SIT0298F } & 1 & -13.4 \\
& 2 & -13.6 \\
& 3 & -13.1 \\
& 4 & -15.8 \\
& 5 & -15.0 \\
& 6 & -13.8 \\
& 7 & -13.3 \\
& 8 & -15.7 \\
& 9 & -13.5 \\
& 10 & -12.9 \\
& 11 & -14.2 \\
& 12 & -14.4 \\
& 13 & -14.4 \\
& 14 & -13.3 \\
& 15 & -14.5 \\
& 16 & -13.1 \\
\hline
\end{tabular}


Table S4: Table showing $\delta^{13} \mathrm{C}$ and $\delta^{15} \mathrm{~N}$ values of 20-30 homogenised grains from each panicle from 11 plants

\begin{tabular}{|c|c|c|c|}
\hline Accession & $\begin{array}{l}\text { Panicle } \\
\text { number }\end{array}$ & $\delta^{13} \mathrm{C}(\%)$ & $\delta^{15} \mathrm{~N}(\%)$ \\
\hline \multirow[b]{4}{*}{ SIT0075I } & 1 & -13.8 & 6.4 \\
\hline & 2 & -14.0 & 6.6 \\
\hline & 3 & -13.9 & 6.7 \\
\hline & 4 & -14.1 & 6.9 \\
\hline \multirow[b]{2}{*}{ SIT0197E } & 1 & -13.0 & 2.4 \\
\hline & 2 & -13.7 & 2.4 \\
\hline \multirow[b]{3}{*}{ SIT0197F } & 1 & -13.1 & 1.5 \\
\hline & 2 & -13.7 & 1.9 \\
\hline & 3 & -13.6 & 0.8 \\
\hline \multirow[b]{2}{*}{ SIT0197G } & 1 & -12.5 & 1.8 \\
\hline & 2 & -12.7 & 2.2 \\
\hline \multirow[b]{4}{*}{ SIT0219G } & 1 & -12.5 & 4.0 \\
\hline & 2 & -12.6 & 3.3 \\
\hline & 3 & -13.1 & 3.2 \\
\hline & 4 & -12.8 & 2.1 \\
\hline \multirow[b]{2}{*}{ SIT0219I } & 1 & -12.9 & 2.6 \\
\hline & 2 & -12.5 & 3.4 \\
\hline \multirow[b]{2}{*}{ SITO298C } & 1 & -12.4 & 6.4 \\
\hline & 2 & -13.4 & 6.3 \\
\hline \multirow[b]{4}{*}{ SIT0298E } & 1 & -12.1 & 4.4 \\
\hline & 2 & -12.5 & 5.1 \\
\hline & 3 & -13.0 & 7.6 \\
\hline & 4 & -12.7 & 3.7 \\
\hline \multirow[b]{6}{*}{ SIT0298F } & 1 & -12.6 & 3.6 \\
\hline & 2 & -12.5 & 3.6 \\
\hline & 3 & -13.2 & 3.7 \\
\hline & 4 & -12.3 & 4.1 \\
\hline & 5 & -13.9 & 3.8 \\
\hline & 6 & -13.2 & 3.6 \\
\hline \multirow[b]{3}{*}{ SIT0298I } & 1 & -12.8 & 3.2 \\
\hline & 2 & -13.7 & 4.8 \\
\hline & 3 & -13.9 & 5.1 \\
\hline \multirow[b]{4}{*}{ SIT0298J } & 1 & -12.4 & 3.8 \\
\hline & 2 & -13.3 & 3.7 \\
\hline & 3 & -12.8 & 3.1 \\
\hline & 4 & -13.6 & 4.5 \\
\hline
\end{tabular}


Table S5: Table showing leaf $\delta^{13} \mathrm{C}$ (all leaves homogenized together), grain $\delta^{13} \mathrm{C}$ and grain $\delta^{15} \mathrm{~N}$ (c. 20-30 grains taken from across all available panicles) from 10 replicates of accession SIT0034 grown in different places in the growth chamber.

\begin{tabular}{|c|ccc|}
\hline Replicate & $\begin{array}{c}\text { Leaf } \mathbf{\delta}^{\mathbf{1 3}} \mathbf{C} \\
\mathbf{( \% )}\end{array}$ & $\begin{array}{c}\text { Grain } \boldsymbol{\delta}^{\mathbf{1 3}} \mathbf{C} \\
\mathbf{( \% )}\end{array}$ & $\begin{array}{c}\text { Grain } \mathbf{\delta}^{\mathbf{1 5}} \mathbf{N} \\
\mathbf{( \% )}\end{array}$ \\
\hline SIT0034A & -13.6 & -12.2 & 6.6 \\
SIT0034B & -14.0 & -13.4 & 5.9 \\
SIT0034C & -13.6 & -12.6 & 6.7 \\
SIT0034D & -13.5 & -12.2 & 6.7 \\
SIT0034E & -13.8 & -12.4 & 6.8 \\
SIT0034F & -13.5 & -12.7 & 6.6 \\
SIT0034H & -14.0 & -12.8 & 6.2 \\
SIT0034G & -13.8 & -12.8 & 6.9 \\
SIT0034I & -13.8 & -12.8 & 5.9 \\
SIT0034J & nd & -12.4 & 6.0 \\
\hline
\end{tabular}

